\title{
Limit-Order Submission Strategies under Asymmetric Information
}

\author{
Lukas Menkhoff \\ Carol L. Osler \\ Maik Schmeling
}

\author{
CESIFO WORKING PAPER No. 3054 \\ CATEGORY 7: MONETARy POLICY AND INTERNATIONAL FinANCE \\ MAY 2010
}
An electronic version of the paper may be downloaded
- from the SSRN website:
- from the RePEc website:
- from the CESifo website:
www.SSRN.com
www.RePEc.org
www.CESifo-group.org/wp




\title{
Limit-Order Submission Strategies under Asymmetric Information
}

\begin{abstract}
This paper provides evidence that informed traders dominate the response of limit-order submissions to shocks in a pure limit-order market. In the market we study, informed traders are highly sensitive to spreads, volatility, momentum and depth. By contrast, uninformed traders are relatively insensitive to all these market conditions. The dominance of the informed over limit-order submissions is magnified by contrasts between them and the uninformed in the use of aggressively-priced limit orders.
\end{abstract}

JEL-Code: G20.

Keywords: limit-order market, order submission, informed traders, market conditions.

\author{
Lukas Menkhoff \\ Leibniz University Hannover \\ Department of Economics \\ Königsworther Platz 1 \\ Germany - 30167 Hannover \\ menkhoff@gif.uni-hannover.de
}

\author{
Carol L. Osler \\ Brandeis International Business School \\ Brandeis University \\ Mailstop 32 \\ USA - Waltham, MA 02454 \\ cosler@brandeis.edu
}

\author{
Maik Schmeling \\ Leibniz University Hannover \\ Department of Economics \\ Königsworther Platz 1 \\ Germany - 30167 Hannover \\ schmeling@gif.uni-hannover.de
}

May 11, 2010

We would like to thank participants at the 11th Conference of the Swiss Society for Financial Market Research, participants at various seminars and an anonymous referee for very helpful comments. Financial support by the German Research Foundation (Deutsche Forschungsgemeinschaft DFG) is gratefully acknowledged. 


\section{Limit-Order Submission Strategies under Asymmetric Information}

This paper undertakes an empirical investigation of limit-order submissions by informed and uninformed traders in a pure limit-order market. The main conclusion is that informed traders dominate the response of aggregate limit orders to market shocks. Informed traders are highly sensitive to changes in spreads, volatility, depth, and momentum while uninformed traders respond very little, if at all, to all these market conditions. A secondary finding is that the dominance of the informed over limit-order submissions partly reflects differences between the informed and the uninformed in their use of aggressively-priced limit orders.

Academic understanding of the influence of information on limit-order submission and thus on a core aspect of liquidity provision has changed dramatically over time. Initially, researchers using static models assumed that uninformed traders would be content to place limit orders and wait for execution while informed traders would impatiently place market orders (e.g., Glosten 1994, and Seppi 1997). This assumption has been challenged by empirical work (Keim and Madhavan 1995) and by theory (Chakravarty and Holden 1995, Harris 1998, Kaniel and Liu 2006). We now understand that informed traders may provide more liquidity than uninformed traders, on average, since the informed do not face picking-off risk (Bloomfield et al. 2005). ${ }^{1}$

The field's focus has by now shifted to the inter-temporal determinants of limit-order submission (e.g., Parlour 1998, Foucault 1999, Goettler et al. 2005, 2009, Rosu 2008, 2009, Foucault et al. 2005), including the response of limit orders to changes in spreads, depth, volatility, and other market conditions. Progress has been hindered by the difficulty of constructing theoretical models of dynamic limit-order markets under asymmetric information, since the models quickly become analytically intractable (Goettler et al. 2005, 2009, Rosu 2009):

\footnotetext{
${ }^{1}$ The informed also provide more liquidity on average in the theoretical model of Goettler et al. (2009). In this setting, however, information itself - which is costly to acquire - does not influence the placement of limit orders. Instead, both choices are the result of a third factor, private valuations.
} 
"A model that incorporates the relevant frictions of limit order markets (such as discrete prices, staggered trader arrivals, and asymmetric information) does not readily admit a closed-form solution" (Goettler et al. 2009, p.68). ${ }^{2}$ The focus of this literature has primarily been on the influence of time-to-execution and trader arrival rates, but many other factors are potentially important. In consequence, we investigate the response of limit-order submissions to changing market conditions empirically rather than theoretically.

We compare the trading of informed and uninformed agents using comprehensive transactions data from the MICEX (Moscow Interbank Currency Exchange), an electronic interdealer market for rubles. Our data permit us to identify individual participants - and to characterize them as informed or uninformed - an advantage that appears to be unique among market-wide limit-order datasets. ${ }^{3}$ We base this characterization on either trading activity or location. The relevance of both criteria is supported in the literature and, more critically, is supported for this particular dataset (Menkhoff and Schmeling 2008, 2010). Both criteria produce the same qualitative results, so we take no position on which is best.

Though much of the information essential to understanding exchange rates is public, asymmetric information is nonetheless central to the functioning of currency markets. Bjønnes et al. (2008) present clear evidence of information asymmetries in the interdealer market. Evans and Lyons (2007) provide evidence of asymmetric information among foreign exchange endusers with respect to the state of the macroeconomy. Clearly the origins of foreign exchange and equity-market information asymmetries must differ. Existing evidence shows that those in foreign exchange arise in part from differences in traders' willingness and ability to forecast macro statistical releases (Osler and Vandrovych 2009; Rime et al. 2010) and other fundamentals; other sources may be relevant as well (Bacchetta and van Wincoop 2006). Osler

\footnotetext{
${ }^{2}$ To date, there are only two models of limit order markets with endogenous order-choice under asymmetric information, neither of which directly addresses the issue on which we focus. Back and Baruch (2007) compares the equilibrium properties of limit order and floor traded-markets, while Goettler et al. (2009) focuses on stationary, symmetric equilibria where strategies are independent of market conditions.

${ }^{3}$ We have anonymous codes of traders but not names of institutions.
} 
(2008) provides a summary of the evidence for information asymmetries in currency markets, and a discussion of how these asymmetries influence spreads and price discovery.

Our comparison of informed and uninformed traders reveals that the informed dominate the average market-wide response of order placement to changes in spreads, volatility, depth (same- and opposite-side), and momentum. Informed agents respond to these market conditions similarly to the overall market but more intensely, while uninformed agents respond either modestly or not at all. Widening spreads and higher volatility, for example, bring a strong shift towards limit orders among informed traders and a far smaller shift among uninformed traders. A similar asymmetry applies to changes in market momentum. The contrast is most extreme for changes in depth, which bring strong responses from the informed and zero estimated response from the uninformed. The contrast is least extreme for expected time to execution. The conclusion that the informed dominate the market's overall response to changing market conditions extends our appreciation of the importance of informed traders in the provision of limit orders and appears to be new to the literature.

Information asymmetries can in most cases explain the stronger responses of the informed to market conditions. Consider, for example, a rise in volatility. If it reflects a transitory rise in order flow, then the reduction in non-execution risk encourages limit-order placement for all agents. If, instead, the rise in volatility reflects a higher information arrival rate, the response will be asymmetric since the intensified uncertainty discourages the uninformed, but not the informed, from placing limit orders (Foucault 1999). The response of the uninformed would thus be smaller than that of the informed.

We also identify a striking contrast between the informed and the uninformed in their use of limit orders priced within the spread. These orders represent an intermediate level of aggressiveness - less aggressive than market orders but more so than other limit orders. We find that the informed treat them as a substitute for market orders while the uninformed treat them as a substitute for patient limit orders. These opposing tendencies intensify the effect of the informed on limit-order submissions and volatility, and further mute the effect of the 
uninformed, an effect best clarified by considering once again a rise in volatility. This prompts both agent types to reduce their placement of market orders and increase their placement of patient limit orders, thus helping volatility return to normal levels (Handa and Schwartz 1996). However, the informed accompany this overall shift by placing more aggressive limit orders, which magnifies their contribution to price stability. The uninformed, by contrast, accompany this overall shift by placing fewer aggressive limit orders, which reduces their contribution to price stability. This contrasting treatment of aggressive limit orders is also, we believe, new to the literature.

Our results suggest that the informed are primarily responsible for the general stability of limit-order submissions and volatility. With respect to resiliency, sometimes defined as the speed with which spreads revert after a shock, we find that traders shift towards limit orders after spreads widen, thus providing resiliency, and that the shift is far stronger for the informed. Likewise we find that the informed are primarily responsible for the stability of depth: After a market order reduces, say, bid depth, informed traders will tend to place more buy limit orders and fewer sell market orders, both of which help restore bid depth. The uninformed, by contrast, are largely unresponsive to changes in depth. Our results are likewise relevant to volatility dynamics. When volatility spikes upward, for example, traders shift towards limit orders which tend to dampen volatility. This shift is far more pronounced for the informed than the uninformed.

Numerous studies examine how aggregate liquidity, in the sense of limit-order submissions, responds to market conditions in limit-order markets (e.g., Griffiths et al. 2000, Hollifield et al. 2004, Ellul et al. 2007, Hasbrouck and Saar 2008, Linnainmaa and Rosu 2008, Lo and Sapp 2008). To our knowledge, this paper is the only one to compare the order choices of informed and uninformed traders after changes in a broad range of conditions. Beber and Caglio (2005) examine the response of market-wide liquidity to a similarly wide range of market conditions, but distinguishes periods when trading is likely to be information-based from other periods. Unfortunately, an analysis of market-wide patterns cannot identify differences between 
the informed and the uninformed. Anand et al. (2005) does examine how order choice varies between informed and uninformed traders, but that paper focuses on the influence of time. In that study of TORQ data, institutional traders are considered informed and others are considered uninformed. Anand et al. (2005) confirms Bloomfield et al.'s (2005) conclusion that the informed shift from market orders to limit orders over the course of the trading day, while the uninformed make the reverse shift. Ranaldo (2004) shows that traders who place large market orders are more sensitive to market conditions than those placing small market orders. However, results in Chakravarty (2001) indicate that trade size is not necessarily a good indicator of information.

Section I, which follows, describes the interdealer ruble market and presents our data. Section II explains our empirical methodology. Section III compares the response of informed and uninformed agents to market conditions and shows that the market's overall response is dominated by the informed. Section IV presents robustness tests and Section V concludes.

\section{Data and market structure}

Our data represent the entire record of order placement and trading on the Moscow Interbank Currency Exchange, or MICEX. ${ }^{4}$ The MICEX serves as the primary electronic interdealer market for the Russian ruble, which is otherwise traded by Russian banks on non-integrated regional exchanges. ${ }^{5}$ The market sets each day's official exchange rate and has a strong influence on the daily rates on each regional exchange.

Our sample period spans the nine trading days from 11 through 21 March, 2002, during which time period 26,859 orders were placed of which 14,109 were market orders and 3,397 were limit orders placed within the spread. Our dataset includes all limit orders (regardless of distance from the best prices), all cancellations, and all trades, so it is possible to reconstruct the entire order book. The dataset also includes, for each order, an anonymous identifying tag for the individual trader placing the order and that trader's location. Limit order-market datasets often

\footnotetext{
${ }^{4}$ Goldberg and Tenorio (1997) analyze an earlier market structure of the MICEX.

${ }^{5}$ The domestic market was segmented from foreign participation by trading restrictions.
} 
do not include enough information to reconstruct the entire order book and they rarely include trader-specific identifying information. ${ }^{6}$

The MICEX has chosen a straightforward structure for its electronic trading platform (known as SELT for System of Electronic Lot Trading): strict price-time priority applies; there are no hidden orders; trading is anonymous until after the transaction; all orders are automatically cancelled at the end of the trading day. Traders are informed of the best bid and best offer together with corresponding depth as well as the price and quantity of the most recent trade. Like some other markets, the MICEX only permits limit orders, so we use the term "market order" interchangeably with "marketable limit order" following Payne (2003) and Hasbrouck and Saar (2008). ${ }^{7}$

The MICEX displays many of the intraday patterns we now associate with limit order markets that have fixed opening and closing times. For example, spreads and volatility follow a U-shaped pattern across the trading day (see Figure 1A), and the U-shape for spreads is asymmetric, with spreads higher at the open than the close. Because all orders are cancelled at the end of the trading day and there is no pre-opening session, limit-order placement on the MICEX is very high when the market opens and the size of the order book rises sharply at first, crests, and then declines slowly. ${ }^{8,9}$ These patterns are shown in Figure 1B, Panel A, where we plot the number of orders outstanding in the limit order book and the share of limit orders submitted in a given time interval relative to overall limit order submission.

\footnotetext{
${ }^{6}$ To our knowledge, only Keim and Madhavan (1995) has identifying information for individual traders.

${ }^{7}$ Market and marketable limit orders are equivalent for orders no bigger than the depth at the quote. For larger quantities, marketable limit orders limit the execution price at the cost of introducing uncertainty about the quantity actually executed (Peterson and Sirri 2002). The use of market orders and marketable limit orders responds similarly to market conditions when both types are available (Ellul et al. 2007).

${ }^{8}$ This is also documented on the Paris Bourse (Biais et al. 1995), the NYSE (Bae et al. 2003), and the Saudi Stock Market (Al-Suhaibani and Kryzanowski 2000).

${ }^{9}$ This inverse U-shaped pattern is similar to those documented for the interbank market in dollar-yen (Ito and Hashimoto 2004), and for active stocks on the NYSE (Lee 1993, Chung et al. 1999), the Paris Bourse (Biais et al. 1995), the Stock Exchange of Hong Kong (Ahn et al. 2001); see also Akram et al. (2009) and Ranaldo (2009). We aggregate buy and sell orders because their placement patterns did not differ much, in contrast to the Swiss Stock Exchange (Ranaldo 2004).
} 
MICEX is similar to other markets in a number of other dimensions, including the share of market orders among all orders $(47 \text { percent })^{10}$ and the mean transaction size $(\$ 50,000)$. Though during our sample period the MICEX was open only one hour per day, the average number of trades per day, 1,568 , is comparable to the average number of trades for individual assets on some of world's the most active limit-order markets: the average NYSE stock examined in Jones and Lipson (2003), for example, traded 1,465 times per day. ${ }^{11}$

\section{Methodology}

This section describes our estimating strategy and then explains how we attempt to distinguish the informed from the uninformed and how we measure market conditions.

\section{A. Estimating strategy}

We focus on how traders choose among orders at three increasing levels of price aggressiveness:

- Level 1: "Patient limit orders": Limit orders priced at the quotes or worse.

- Level 2: "Aggressive limit orders": Limit orders priced within the quotes.

- Level 3: "Market orders": Limit orders priced better than the opposite-side quote. Many studies of order choice focus only on the broad distinction between market and limit orders (e.g., Handa and Schwartz 1996, Parlour 1998, Bae et al. 2003, Bloomfield et al. 2005). Limit-order submissins contribute directly to depth or to cumulative depth, and depth is one of the three critical dimensions of liquidity. This does not help, however, in evaluating how order choice affects spreads or resiliency, the second and third critical dimensions of liquidity. For this purpose we join other researchers, including Biais et al. (1995), Griffiths et al. (2000), Goettler et al. (2005), Ellul et al. (2007), and Tkatch and Kandel (2008), in distinguishing aggressive limit orders - meaning those priced within the spread - from patient limit orders -

\footnotetext{
${ }^{10}$ For the share of market orders in other markets see Biais et al. (1995), Harris and Hasbrouck (1996), Bae et al. (2003), Hollifield et al. (2004), and Griffiths et al. (2000).

${ }^{11}$ The market has since extended its trading hours.
} 
meaning those priced at or behind the quotes. Aggressive limit orders represent 11 percent of all limit orders in our sample. ${ }^{12}$

We evaluate how order choice, observed at the level of individual orders, responds to market conditions by estimating ordered logit regressions of order aggressiveness. The dependent variable is the level of order aggressiveness and for each type of trader - informed and uninformed. We consider eight forces that might influence order choice: the spread, volatility, depth on the same side, depth on the opposite side, momentum, trade duration, trading volume, and time. ${ }^{13}$ Our main regressions distinguish the informed from the uninformed but for comparability with other studies we also estimate regressions that do not disaggregate traders. We use maximum likelihood estimation (Campbell et al. 1997) and bootstrapped $t$-values.

Two choices in our methodology deserve comment. First, we use ordered logit regressions, though related papers by Griffiths et al. (2000) and Hasbrouck and Saar (2008) use multinomial logit regressions instead. Multinomial regressions were required in those cases because their datasets included trade variables that do not fit a natural ordering, specifically cancellations or fleeting orders. Our trade variables do fit a natural ordering, and because they incorporate the associated information our ordered logit regressions will be more efficient. To confirm this decision we ran a parallel slopes test, which indicates that multinomial logit regressions are not statistically preferable to ordered logit regressions for our data. In any case, results from multinomial logit regressions, suppressed to save space, are not qualitatively different from those reported below. ${ }^{14}$

Second, though we report the results of separate regressions for informed and uninformed traders we could also have used single-equation regressions in which the informed and uninformed are distinguished by dummy variables interacted with the key market conditions. We focus on the separate-equation regressions since they permit a straightforward calculation of

\footnotetext{
${ }^{12}$ Our results are not sensitive to whether "aggressive orders" are defined to include or exclude orders at the quotes.

${ }^{13}$ Keim and Madhavan (1995) include two other conditioning variables, order size and order direction, neither of which is statistically significant.

${ }^{14}$ Ideally, one would estimate the simultaneous determination of quantities and prices. Due to the paucity of good instruments, however, we follow standard practice and concentrate on prices. When we disaggregate trades into two size categories our qualitative results are largely unchanged.
} 
marginal effects (which are the main object of interest in discrete choice models) and because they are less constrained than the single-equation interaction regressions (the latter constrain the intercepts to be equal between groups). For robustness we ran both types and the results differ only marginally across settings.

\section{B. Proxies for information}

Central to our analysis is the distinction between informed and uninformed traders. We use two proxies suggested by the literature: trading activity and location. We take no position on the relative merits of these two proxies and our qualitative conclusions are immune to the choice.

The use of trading activity as a proxy for information is motivated by the importance of customer trades as a source of private information in foreign exchange (see Lyons 2001, Bjønnes et al. 2007, Osler et al. 2007, Ramadorai 2008). Such information is so important that dealers actively seek to increase their business with the customers that bring them the most information (Osler et al. 2007, Ramadorai 2008), so they can exploit that private information when trading in the interdealer market (Bjønnes et al. 2008). The largest and most active banks are almost invariably those with the most active customers.

The use of trading location as a proxy for the possession of information is inspired by research showing that proximity to decision-makers has information value in foreign exchange markets (Peiers 1997, Covrig and Melvin 2002) as well as equity markets (Coval and Moskowitz 2001, Hau 2001, Malloy 2005). Though some evidence exists that location may be not relevant in the most sophisticated currency markets (Bjønnes et al. 2008), it may still be relevant in emerging markets like Russia: it is well-known, for example, that favored individuals in Mexico were informed about the peso's collapse in December 1994 the night before it occurred. More broadly, the best-informed agents in foreign exchange markets appear to be large financial institutions and central banks (Lyons 2001, Marsh and O'Rourke 2005, Osler et al. 2008). In Russia, most such institutions are located in Moscow and St. Petersburg.

Two companion studies analyzing the information content of MICEX trades find that location and trading activity may both be relevant. Menkhoff and Schmeling (2010) shows that 
order flow from the most active MICEX traders is more informative than order flow originating from smaller traders. Menkhoff and Schmeling (2008) shows that trades carried out by traders located in the financial center have a substantial permanent price impact while traders located in peripheral cities have only a transitory price impact. Critically, this is true even after controlling for trade size and trader activity. (Note that these companion pieces analyze information content of trades by looking subsequent returns, while the present paper uses those results to justify our disaggregation of traders in analyzing how order execution responds to market shocks including previous returns.)

When trading activity is the proxy for information, traders are first ranked by their total trading volume and then divided into four groups that each account for one quarter of total trading. The 21 traders in the top group are taken to be informed; the 546 traders in the bottom group are taken to be uninformed. When location is the proxy for information, the informed are 461 traders from Russia's two financial centers, Moscow and St. Petersburg, while the uninformed are 261 traders from the exchange's six Periphery regions, Ekaterinburg, N.

Novgorod, Novosibirsk, Rostov, Samara, and Vladivostock. The traders labelled as informed and uninformed vary quite a bit between the two proxies. The group of least active traders comprises 291 of the 461 Center traders and 255 of the 261 Periphery traders. The group of most active traders includes only 20 of the 461 Center traders and one Periphery trader.

The distribution of order submission activity for these groups of traders is provided in Table 1. Encouragingly, the traders we label "informed" have much stronger tendencies to place market orders and tend to place larger orders than the traders we label uninformed. Analyzing their trading behavior in more detail, we do not find that informed traders hide in the crowd of uninformed traders regarding their overall trading activity as hypothesized by Kumar and Seppi (1994). Panel B of Figure 1B presents activity of limit-order submissions for informed and uninformed traders for twelve five-minute intervals over the trading day (as in Panel A of that figure). This figure indicates that there is a structural difference in trading behavior between informed and uninformed traders. Uninformed traders submit most of their limit orders early in 
the day and the rate of submission declines fairly monotonically; by contrast, the rate of limitorder placement by informed traders is essentially U-shaped, with peaks at each end of the day.

The extent of the difference in trading behavior is further indicated by Figure 2, which shows "submission" and "taking rates" for informed and uninformed traders. As in Bloomfield et al. (2005), submission rates are defined as the share of submitted limit orders relative to submitted market and limit orders and taking rates are defined as market orders relative to market orders and executed limit orders. There is a striking similarity between the figure and experimental results in Bloomfield et al. (2005), where traders can be exactly classified as informed or uninformed. The uninformed rely relatively more on limit orders in the early parts of the session and less on limit orders towards the end of the trading session (see e.g. Madhavan et $a l .$, 1997), so their "submission rate" declines over the day whereas their "taking rate" rises.

Informed traders show the opposite pattern, relying more on market orders early in the day and act as liquidity provides ("market makers") in the later part of the session. These results are robust to using another information proxy, i.e. the location of traders. We interpret this confirmation of the Bloomfield et al. (2005) experiment as indication for the usefulness of our informed-uninformed-classification.

\section{Measuring market conditions}

Descriptive statistics for market conditions on are provided in Table 2. Our variable definitions are largely taken from the literature (e.g., Hasbrouck and Saar 2008).

- Spread is measured as the absolute difference between the best bid and ask prices visible on the trading screen just prior to the submission of the order.

- Volatility is measured as the standard deviation of midquote changes over the 20 seconds prior to the submission of the order. ${ }^{15}$

- Depth: Same-side (opposite-side) depth is measured as the volume at the bid (ask) just prior to a buy order's submission and as the volume at the ask (bid) just prior to a sell order's

\footnotetext{
${ }^{15}$ A similar measure is referred to as "transient volatility" in Ahn et al. (2001) and in Ranaldo (2004).
} 
submission, respectively. Cumulative depth is available in our dataset, of course, but it is not relevant since we must condition on information available to traders and the MICEX only tells them depth at the best prices. In any case, depth at the best price averages over fifty percent more than the average market order, so few market orders walk up the book.

- Momentum is measured in terms of order flow. We cumulate signed transaction indicators over the 20 seconds just prior to the submission of an order, where positive (negative) transactions are triggered by market buy (sell) orders. We direction-adjust order flow by multiplying it by minus one if the current order is a sell order.

- Trading volume is measured as the cumulative trading volume - i.e. the total volume of market orders - over the 20 seconds just prior to the submission of an order.

- Trade duration is measured as the time in seconds between the last two trades. Duration is known to be strongly autocorrelated (Engle and Russell 1998) so we tend to interpret duration as a proxy for expected time to execution. Theoretical arguments in Rosu (2008) suggest that higher trader arrival rates should encourage the submission of aggressive orders by reducing expected time to execution. Tkatch and Kandel (2008) and Linnainmaa and Rosu (2008) provide empirical evidence consistent with that analysis.

- $\quad$ Time is measured as a linear trend of 60 trading minutes.

In Section IV we provide evidence that the results are not sensitive to these definitions.

\section{Determinants of limit-order submission strategies}

In this section we investigate how the response of order choice to market conditions varies between informed and uninformed traders. We first look broadly at the choice between market orders and all limit orders. We then look closely at how traders use aggressive limit orders and at relations between limit-order submissions and liquidity.

\section{A. The informed dominate limit-order submissions}

The broad picture painted by our empirical results is quickly summarized. Informed traders generally respond far more strongly to market shocks than uninformed traders. This 
message comes from both Table 3A, in which information is proxied by trading activity, and $\underline{\text { Table } 3 \mathrm{~B}}$, in which information is proxied by location. In some cases the informed are the only agents to respond; in other cases the uninformed do respond but the informed respond more strongly. The traders' responses to changing spreads, volatility, depth, momentum, and time are easily explained with reference to the literature (Handa and Schwartz 1996, Parlour 1998, Goettler et al. 2005, Bloomfield et al. 2005), though the response to changing trade duration is more difficult to interpret. In most cases the difference between the informed and the uninformed can be explained in terms of information asymmetries and the immunity of the informed to picking-off risk.

Because of their strong responses, the informed dominate the market-wide response of liquidity to market shocks, reported in Table 4. The responses are generally consistent with comparable results for other markets (see Chung et al. 1999, Griffiths et al. 2000, Ahn et al. 2001, Bae et al. 2003, Hollifield et al. 2004, Ranaldo 2004, Beber and Caglio 2005, Ellul et al . 2007, Hasbrouck and Saar 2008, Rakowski and Beardsley 2008). ${ }^{16}$ We next examine these responses individually.

Spreads: The familiar tendency of traders to choose less aggressive orders in response to widening spreads aptly illustrate the dominance of the informed over liquidity dynamics. When information is proxied by trading activity (Table 3A, line 1), a one-standard-deviation widening of the spread is estimated to raise the likelihood of an informed limit order by over 12 percentage points from a baseline of 35 percent. By contrast, the same shift raises the likelihood of an uninformed patient limit order by only 6 percentage points from a baseline of 45 percent.

This contrast is equally striking when information is proxied by location, in which case a one-standard-deviation rise in the spread increases the likelihood that the next informed order is a patient limit order by roughly 10 percentage points from a baseline percentage of 36 percent but the wider spread is estimated to have no effect at all on the uninformed. The differences

\footnotetext{
${ }^{16}$ Biais et al. (1995), Griffith et al. (2000), and Ellul et al. (2007) use finer disaggregations than our own. Since the ordinal ranking on the left-hand-side should continue to work if some adjacent categories are combined to form broader categories it seems unsurprising that our qualitative results for the entire sample line up closely with theirs.
} 
between informed and uninformed traders are statistically significant for both information proxies, as indicated by the single-equation regressions. The contrast between the informed and the uninformed is always consistent across our two information proxies so we focus henceforth on the trading-activity proxy.

This mingling of a strong response from the informed with a muted response from the uninformed generates, as one would expect, a modest response in the market as a whole. A onestandard-deviation widening of the spread increases by about 9 percentage points the likelihood that the next order from any trader is a limit order, relative to its baseline value of 48 percent. Unsurprisingly, the response is not quite statistically significant.

These findings are consistent with results in Jones and Lipson (2003), who find that institutional traders on the NYSE - whom they take to be informed - are sensitive to spreads while retail traders are not. They are also consistent with the theoretical analysis in Foucault et al. (2005), who find that the average time between trades rises with spreads.

Following Bloomfield et al. (2005), we hypothesize that the more muted response of the uninformed to rising spreads reflects information asymmetries, without which the uninformed and the informed would shift equally towards limit orders in response to the higher cost of immediacy. When information is asymmetric, however, a wider spread could reflect an intensification of these asymmetries that would discourage the uninformed - but not the informed - from shifting towards limit orders. In short, both the informed and the uninformed have an incentive to shift towards limit orders but the uninformed also have an incentive to shift in the other direction, so the response of the uninformed is naturally more muted.

Volatility: The dominance of the informed is equally strong with respect to volatility shocks. For the informed, a one-standard-deviation rise in volatility raises the probability of a limit order (of any sort) by roughly 17 percentage points. For the uninformed, the point estimate suggests that the probability rises by just 6 percentage points though the point estimate is not quite significant. Thus the informed dominate the market's overall tendency to shift towards limit orders after a rise in volatility. 
This difference, too, can be explained in terms of information asymmetries. For both the informed and the uninformed, higher volatility brings lower non-execution risk and thereby encourages limit-order placement (Handa and Schwartz 1996). High volatility could also, however, reflect a higher frequency of information arrival (Easley et al. 2002) or a change in the market's underlying information structure, with each new bit of information having a stronger influence on the asset's true value (Foucault 1999). Such changes in the information environment could discourage limit-order placement by the uninformed. As with spreads, the overall response of the uninformed, as a weighted average of two effects with opposite sign, should thus be less positive than that of the informed. ${ }^{17}$

Depth: The dominance of the informed over the market's response to changing market conditions is particularly extreme with respect to depth. A one-standard-deviation increase in, say, buy-side depth, raises the likelihood of informed market buy orders by 11 percentage points (relative to a 25 percent baseline) and reduces the likelihood of informed market sell orders by 16 percentage points (relative to a 40 percent baseline). The depth coefficients for the uninformed are economically small and statistically insignificant (a conclusion supported by the single-equation regressions), so the market's aggregate responses (Table 4, lines 3 and 4 ) are due entirely to the informed. ${ }^{18}$ The relatively muted response of the uninformed cannot readily be explained in terms of information asymmetries or other forces highlighted in the literature, such as non-execution risk. We leave it as a puzzle. ${ }^{19}$

Momentum: The dominance of the informed over the market's average response to shocks is also clear with respect to momentum. For both the informed and the uninformed the response to a sequence of, say, market buy orders is to increase the likelihood that the next buy order is a market order and that the next sell order is a limit order. Though the uninformed do

\footnotetext{
${ }^{17}$ In unreported regressions we also find that higher volatility leads to a larger probability that uninformed traders cancel existing limit orders, suggesting that they view picking-off risk as rising with volatility.

${ }^{18}$ Hasbrouck and Saar (2009) find that lower depth on the same side increases both market orders and regular limit orders, while "fleeting" limit orders decline. They attribute this to "correlated trading."

${ }^{19}$ Our results are qualitatively robust to using other measures of depth, specifically depth at the five best quotes and aggregate depth on the bid or ask side of the complete limit order book. We present results for depth at the best bid or ask since this depth is visible and it is also standard in the literature.
} 
respond to momentum shocks, the difference between their response and that of the informed is still striking. After a one-standard deviation increase in the net of market buy and market sell orders, the likelihood of a market buy rises for informed traders by about 12.5 percentage points from its unconditional mean of 53 percent, and for uninformed traders by only 4 percentage points from its unconditional mean of 37 percent. According to the single-regression estimates these differences are statistically significant for both information proxies.

This general direction of response could reflect the theoretical possibility that order flow (Evans and Lyons 2007) and/or past returns (Brown and Jennings 1989) provide information about future returns. If so, the more muted response of the uninformed to order-flow momentum could reflect information asymmetries: the possibility that upward momentum, for example, reflects a rise in the asset's fundamental value known only to the informed would discourage the use of limit sell orders by the uninformed. The qualitative response could also reflect the known tendency for large orders to be split into many smaller transactions. In this case the more muted response of the uninformed could reflect a natural tendency for smaller banks to have smaller trading needs and therefore to split orders less frequently (Table 1).

Trading volume: Trading volume proved insignificant in all cases. We included this variable because it has occasionally been significant in other studies, notably Hasbrouck and Saar (2008), Chung et al. (1999) and also Kaul and Sapp (2009).

Trade duration: A rise in trade duration is associated with an increase in the tendency to place limit orders for both informed and uninformed traders. After a one-standard deviation increase in lagged trade duration, the likelihood of a limit order increases for informed traders by about 14 percentage points and for uninformed by about 11 percentage points. This is the one variable for which the estimated difference between the informed and the uninformed is not strong: indeed, when we use the less-powerful proxy for information, location, the difference disappears. This variable was intended to capture the influence of expected time to execution, an increase in which should discourage limit orders according to existing theory (Foucault et al. 2005; Rosu 2008, 2009). Evidence for this hypothesis is provided in Tkatch and Kandel (2008). 
We offer the following potential explanation of this otherwise puzzling result. In some markets, like the NYSE, trading tends to occur most frequently at the market open, when information asymmetries are strongest because trading has been suspended during an extended overnight period (Madhavan et al. 1997). This is also true for the MICEX. If so, the trade duration variable might capture these shifts in the information environment. Higher trade duration would reflect a dearth of new information arrivals and would therefore be associated with the relatively heavy use of limit orders for both, the informed and the uninformed, consistent with our results. The informed would rationally make markets because they think the asset is well-priced (as definitely happens sometimes in foreign exchange) and the uninformed would rationally shift towards limit-orders when picking-off risk is low

Time: Informed traders on the MICEX shift towards limit orders over the trading day, while the informed shift in the opposite direction - from limit orders to market orders. This is consistent with experimental results reported in Bloomfield et al. (2005) and discussed above (see Figure 2). This is the one market condition for which the uninformed dominate the market's overall behavior. The opposing shifts of informed and uninformed traders explain why the MICEX's overall shift towards market orders across the trading day is not substantial. These diverging patterns could also explain why the average direction of change varies across markets: Beber and Caglio (2005) find trading on the NYSE shifts modestly towards market orders over the day whereas Ellul et al. (2007) find the reverse.

\section{B. Asymmetric treatment of aggressive limit orders}

The pattern of marginal effects shown in Table 3 reveals that the dominance of the informed over the MICEX's response to changing conditions is reinforced by three striking differences between the informed and the uninformed in their use of aggressive limit orders. First, the informed and the uninformed respond in the opposite direction to changes in market conditions. Second, for the informed the sign of the marginal effect is almost always the opposite from the sign of the marginal effect for market orders, which implies that the informed treat aggressive limit orders as an alternative to market orders. By contrast, the sign of the marginal 
effect for the uninformed is almost always the same as the sign for market orders, implying that the uninformed generally treat aggressive limit orders as an alternative to patient limit orders. Third, the placement of aggressive limit orders by the informed is fairly sensitive to changing market conditions while their placement by the uninformed is not. For the informed, the marginal effects for aggressive limit orders are around 20 percent of the marginal effects for passive limit orders, while the corresponding fraction for the uninformed is closer to five percent.

These patterns hold for spreads, volatility, same-side and opposite-side depth, momentum, and time; the patterns also hold for both information proxies. Consider, for example, a one-standard-deviation rise in volatility. This brings a higher likelihood that the informed place aggressive limit orders and a lower likelihood that the uninformed place such orders. The change for the informed is estimated to be 3 percentage points relative to a 10 percent baseline frequency, while the change for the uninformed is estimated to be only 0.6 percent relative to an 11 percent baseline. Though this point estimate is only significant at the ten percent level, the corresponding estimate for the location proxy is significant and implies the same response.

There are few theoretical works with which to compare these results. One notable exception is Harris (1998), who concludes that uninformed traders should place more aggressive limit orders as deadlines near. The end of the day serves as a trading deadline for the most foreign exchange dealers, since they generally prefer not to carry inventory overnight (Bjønnes and Rime 2005). Another notable exception, Foucault et al. (2005), shows that resiliency increases with the share of impatient traders relative to patient traders. There is, unfortunately, no clear mapping between their impatient traders and our informed traders.

\section{Relations between limit-order submissions and liquidity}

The literature typically identifies three dimensions of liquidity: spreads, depth, and resiliency. Of these, the only dynamic property is resiliency - defined as the speed with which prices revert to fundamental values after a demand shock (Kyle 1985), but often identified in practice with the return of spreads to normal after a demand shock (Parlour and Seppi 2007). The contrasting treatment of aggressive limit orders just outlined suggests that resiliency is primarily 
provided by informed traders. Consider a one-standard deviation rise in the spread from its unconditional mean. This leads both the informed and the uninformed to place more patient limit orders (though the shift is stronger for the informed). Thus both the informed and the uninformed contribute to depth. Only the informed, however, help narrow the spread by placing more aggressive limit orders. A one-standard-deviation rise in spreads raises the conditional likelihood that an informed trader places an aggressive limit order by more than two percentage points $-\mathrm{a}$ large change relative to the unconditional likelihood of 11 percent. By contrast, the uninformed make no change in their placement of aggressive limit orders. ${ }^{20}$ Ellul et al. (2007) finds that the placement of aggressive limit orders on the NYSE increases after spreads widen: our results suggest that this could be due predominantly to the informed.

The order-choice responses identified here stabilize the depth dimension of liquidity as well as the spread dimension. A rise in buy-side depth, for example, discourages buy limit orders while encouraging sell market orders. Both of these shifts tend to offset the initial shift, thereby stabilizing depth. As noted earlier, only the responses of informed traders are statistically significant, so this stability property is also dominated by the informed.

Our results are also related to the dynamics of volatility. Handa and Schwartz (1996) discuss an "ecological" process, analyzed further in Bae et al. (2003), whereby volatility shocks induce endogenous shifts in order choice that return volatility to normal levels. Our results suggest that this endogenous stabilizing response is dominated by the informed. A rise in volatility induces the informed to shift strongly towards limit orders, while the uninformed show only a modest increase in their likelihood of placing patient limit orders.

\section{Robustness tests}

Our results are robust to numerous modifications of our empirical methodology, as we show in this section. In Table 5 we examine the influence of alternative definitions of volatility, momentum, and time. In Specification I, volatility is measured as the high-low range over the

\footnotetext{
${ }^{20}$ Both of these outcomes are entirely reasonable, since aggressive orders represent an intermediate level of aggressiveness between two extremes.
} 
preceding 20 seconds (Bae et al. 2003 also uses this measure). In Specification II signed orderflow momentum is replaced by signed price momentum, following Hasbrouck and Saar (2008), measured here as the cumulative (direction-adjusted) log midquote change over the 20 seconds just prior to the submission of an order. In Specification III we partition the trading day into six intervals and assign separate dummies to each one, rather measuring time as a linear trend; this permits non-monotonic changes over the trading day. We report results when the definitions are applied to informed and uninformed traders separately with information proxied by trading activity. (Results with information proxied by location are quite similar and are suppressed to save space.) For both information proxies, regressions with these alternative variable definitions imply the same qualitative conclusions described above. ${ }^{21}$

The empirical analyses of Biais et al. (1995), Griffiths et al. (2000), and Ellul et al. (2007) suggest that our overall specification might be improved by including a lagged dependent variable. We use the approach of Biais et al., in which the lagged variable is coded one if the last order was a market order of the same direction as the current order and zero otherwise. In these regressions ( $\underline{\text { Table } 6}$ ), the lagged variable has the expected sign and is highly significant but our main qualitative conclusions remain unchanged.

For comparison with Griffiths et al. (2000) and Hasbrouck and Saar (2008) we repeat our analysis using multinomial logit regressions. The results confirm that (i) the informed respond more strongly to all types of shocks and (ii) the informed generally use aggressive limit orders as substitutes for market orders while the uninformed use them as substitutes for patient limit orders. Due to the loss of information, however, these estimates are less efficient and some coefficients are no longer significant. ${ }^{22}$

Finally, we investigate robustness with respect to two interaction terms and additional variables that may better capture expected time-to-execution. ${ }^{23}$ The interaction of spread and

\footnotetext{
${ }^{21}$ In unreported regressions we (i) measure volatility as the sum of absolute midquote returns over the preceding 20 seconds and (ii and iii) measure the conditioning variables over the 40 or 60 seconds prior to an order's submission. These regressions leave our qualitative conclusions unchanged. Results are available on request.

${ }^{22}$ These results are available upon request.

${ }^{23}$ We thank an anonymous referee for pointing out these additional tests.
} 
opposite-side depth should control for the possibility that small spreads coincide with low depth, so traders can expect large orders to walk up the book (see e.g. Wuyts 2008). As shown in Table 7, this interaction term is never significant, which may reflect the relatively small number of orders in our dataset large enough to exhaust depth at the quotes. ${ }^{24}$

The interaction between volatility and depth is intended to identify whether trader responses differ when volatility is accompanied by low depth. Suppose that sometimes volatility is just a mechanical consequence of low depth, rather than a reflection of heightened information asymmetries. In such cases the relatively high execution priority of new limit orders could encourage their placement by all traders and the interaction term would have a positive coefficient. Instead, the coefficients are negative and significant. This effect is especially strong for the uninformed traders, corroborating our argument that asymmetric information is important for understanding order choice. When liquidity is high, volatility may be more likely to reflect asymmetric information than the mechanics of the limit-order book and the uninformed would be most sensitive to these information asymmetries.

We also investigate whether the duration of trades on the same side of the order book has a different effect as the duration of trades on the opposite side of the book. As shown in Table 7, higher duration on both sides of the book tends to reduce order aggressiveness, as found earlier, but duration on the same side of the book ("Duration, Same Side") matters most for order choice. Our main conclusions regarding the effect of spreads, volatility, depths, and momentum on order choice are unaffected by the disaggregation of trade duration.

Finally, we control for the arrival rate of traders, which we proxy with the monetary value of all orders submitted over the last 20 seconds (including both market and limit orders) following Tkatch and Kandel (2008). A higher arrival rate should lower expected time-toexecution (Foucault et al., 2005) and thus lead to less aggressive order submissions. Our results in Table 7 show a negative coefficient for this variable, as this hypothesis predicts, but the effect is insignificant in most regressions.

\footnotetext{
${ }^{24}$ We find similar insignificant results when we look at other depth measures (same side depth, average depth etc.).
} 


\section{Conclusion}

Research on limit order markets shows that it was incorrect to assume, as researchers did initially, that informed traders place only market orders and uninformed place only limit orders. It now appears that the informed may place more limit orders, on average, than the uninformed (Bloomfield et al. 2005). Our paper moves beyond this static analysis to examine the determinants of limit-order submission strategies by informed and uninformed agents, investigation of which has been impeded at the theoretical level by the inherent complexity of these markets. Our data, which pertain to the interdealer market for rubles, are unique in this line of literature since they include trader identifying information. This permits us to partition traders into the informed and uninformed. We compare how these agents' order choice responds to changes in spreads, volatility, depth, momentum, trading volume, trade duration, and time of day.

The results, which are robust to numerous modifications of the central estimation strategy, indicate that informed traders dominate the market's overall response to changing market conditions. The uninformed are completely insensitive to certain market conditions and far less sensitive than the informed to the other conditions. A secondary conclusion is that the informed and uninformed treat aggressive limit orders quite differently, and that this difference magnifies the dominance of the informed over limit-order submissions. 


\section{References}

Ahn, Hee-Joon, Kee-Hong Bae and Kalok Chan (2001), Limit Orders, Depth, and Volatility: Evidence from the Stock Exchange of Hong Kong, Journal of Finance, 56:2, 767-788.

Akram, Q. Farooq, Dagfinn Rime and Lucio Sarno (2009), Does the Law of One Price Hold in International Financial Markets? Evidence from Tick Data, Journal of Banking and Finance, 33, 1741-1754.

Al-Suhaibani, Mohammad and Lawrence Kryzanowski (2000), An Exploratory Analysis of the Order Book, and Order Flow and Execution on the Saudi Stock Market, Journal of Banking and Finance, 24, 1323-1357.

Anand, Amber, Sugato Chakravarty and Terrence Martell (2005), Empirical Evidence on the Evolution of Liquidity: Choice of Market versus Limit Orders by Informed and Uninformed Traders, Journal of Financial Markets, 8, 288-308.

Bacchetta, Philippe and Eric van Wincoop (2006), Can Information Heterogeneity Explain the Exchange Rate Determination Problem? American Economic Review, 96, 552-576.

Back, Kerry and Shmuel Baruch (2007), Working Orders in Limit-Order Markets and Floor Exchanges, Journal of Finance, 62, 1589-1612.

Bae, Kee-Hong, Hasung Jang and Kyung Suh Park (2003), Traders' Choice between Limit and Market Orders: Evidence from NYSE Stocks, Journal of Financial Markets, 6, 517-538.

Beber, Alessandro and Cecilia Caglio (2005), Order Submission Strategies and Information: Empirical Evidence from the NYSE, Working Paper 146, Université de Genève.

Biais, Bruno, Pierre Hillion and Chester S. Spatt (1995), An Empirical Analysis of the Limit Order Book and the Order Flow in the Paris Bourse, Journal of Finance, 50:5, 16551689.

Bjønnes, Geir H. and Dagfinn Rime (2005), Dealer Behavior and Trading Systems in Foreign Exchange Markets, Journal of Financial Economics, 75:3, 571-605.

Bjønnes, Geir, Carol Osler and Dagfinn Rime (2008), Asymmetric Information in the Interbank Foreign Exchange Market, Presented at the Third Annual Conference on Market Microstructure, Budapest, Hungary, September 15, 2007.

Bloomfield, Robert, Maureen O'Hara and Gideon Saar (2005), The "Make or Take" Decision in an Electronic Market: Evidence on the Evolution of Liquidity, Journal of Financial Economics, 75, 165-199.

Brown, David and Robert Jennings (1989), On Technical Analysis, Review of Financial Studies, 4:2, 527-551.

Campbell, John Y., Andrew W. Lo and A. Craig MacKinlay (1997), Econometrics of Financial Markets, Princeton: Princeton University Press.

Chakravarty, Sugato (2001), Stealth-trading: Which Trader's Trades Move Stock Prices?, Journal of Financial Economics, 61:2, 289-307.

Chakravarty, Sugato and Craig W. Holden (1995), An Integrated Model of Market and Limit Orders, Journal of Financial Intermediation, 4, 213-241.

Chung, Kee H., Bonnie F. Van Ness and Robert A. Van Ness (1999), Limit Orders and the BidAsk Spread, Journal of Financial Economics, 53, 255-287.

Coval, Joshua D. and Tobias J. Moskowitz (2001), The Geography of Investment: Informed Trading and Asset Prices, Journal of Political Economy, 109:4, 811-841. 
Covrig, Vicentiu and Michael Melvin (2002), Asymmetric Information and Price Discovery in the FX Market: Does Tokyo Know more about the Yen?, Journal of Empirical Finance, 9, 271-285.

Easley, David, Soeren Hvidkjaer and Maureen O'Hara (2002), Is Information Risk a Determinant of Asset Returns? Journal of Finance, 57, 2185-2221.

Ellul, Andrew, Craig Holden, Pankaj Jain and Robert Jennings (2007), Order Dynamics: Recent Evidence from the NYSE, Journal of Empirical Finance, 14, 636-661.

Engle, Robert, and J. Russell (1998), Autoregressive Conditional Duration: A New Model for Irregularly Spaced Transactions Data, Econometrica, 66, 1127-1162.

Evans, Martin D.D. and Richard K. Lyons (2007), Exchange-rate Fundamentals and Order Flow, NBER Working Paper 13151.

Foucault, Thierry (1999), Order Flow Composition and Trading Costs in a Dynamic Limit Order Market, Journal of Financial Markets, 2, 99-134.

Foucault, Thierry, Ohad Kadan and Eugene Kandel (2005), Limit Order Book as a Market for Liquidity, Review of Financial Studies, 18, 1171-1217.

Foucault, Thierry, Sophie Moinas and Erik Theissen (2007), Does Anonymity Matter in Electronic Limit Order Markets?, Review of Financial Studies, 20, 1707-1747.

Glosten, Lawrence R. (1994), Is the Electronic Open Limit Order Book Inevitable?, Journal of Finance, 49:4, 1127-1161.

Goldberg, Linda S. and Rafael Tenorio (1997), Strategic Trading in a Two-sided Foreign Exchange Auction, Journal of International Economics, 42, 299-326.

Goettler, Ronald L., Christine A. Parlour and Uday Rajan (2005), Equilibrium in a Dynamic Limit Order Market, Journal of Finance, 60:5, 2149-2192.

Goettler, Ronald L., Christine A. Parlour and Uday Rajan (2009), Informed Traders and Limit Order Markets, Journal of Financial Economics, 93, 67-87.

Griffiths, Mark D., Brian F. Smith, D. Alasdair S. Turnbull and Robert W. White (2000), The Costs and Determinants of Order Aggressiveness, Journal of Financial Economics, 65:1, 65-88.

Handa, Puneet and Robert A. Schwartz (1996), Limit Order Trading, Journal of Finance, 51:5, $1835-1861$.

Harris, Lawrence (1998), Optimal Dynamic Order Submission Strategies in some Stylized Trading Problems, Financial Markets, Institutions, and Instruments, 7, 26-74.

Harris, Lawrence and Joel Hasbrouck (1996), Market versus Limit Orders: the Superdot Evidence on Order Submission Strategy, Journal of Financial and Quantitative Analysis, 31, 213-231.

Hasbrouck, Joel and Gideon Saar (2009), Technology and Liquidity Provision: The Blurring of Traditional Definitions, Journal of Financial Markets, 12, 143-172.

Hau, Harald (2001), Location Matters: An Examination of Trading Profits, Journal of Finance, $56: 3,1959-1983$.

Hollifield, Burton, Robert A. Miller and Patrik Sandås (2004), Empirical Analysis of Limit Order Markets, Review of Economic Studies, 71:4, 1027-1063.

Ito, Takatoshi and Yuko Hashimoto (2004), Microstructure of the Yen/Dollar Foreign Exchange Market: Patterns of Intra-Day Activity Revealed in the Electronic Broking System, NBER Working Paper 10856.

Jones, Charles M. and Marc L. Lipson (2003), Are Retail Orders Different?, Working Paper, Columbia University. 
Kaniel, Ron and Hong Liu (2006), So what Orders Do Informed Traders Use?, Journal of Business, 79, 1867-1913.

Kaul, Aditya and Stephen Sapp (2009), Trading Activity, Dealer Concentration and Foreign Exchange Market Quality, Journal of Banking and Finance, 33, 2122-2131.

Keim, Donald B. and Ananth Madhavan (1995), Anatomy of the Trading Process: Empirical Evidence on the Behavior of Institutional Traders, Journal of Financial Economics, 37:3, 371-398.

Kyle, Albert (1985), Continuous Auctions and Insider Trading, Econometrica 53: 1315-1335.

Lee, Charles M.C. (1993), Market Integration and Price Execution for NYSE-Listed Securities, Journal of Finance, 48:8, 1009-1038.

Linnainmaa, Juhani and Ioanid Rosu (2008), Time Series Determinants of Liquidity in a Limit Order Market, AFA 2009 San Francisco Meetings Paper.

Lo, Ingrid and Stephen G. Sapp (2008), The Submission of Limit Orders or Market Orders: The Role of Timing and Information in the Reuters D2000-2 System, Journal of International Money and Finance, 27, 1056-1073.

Lyons, Richard K. (2001), The Microstructure Approach to Exchange Rates, Cambridge: MIT Press.

Madhavan, Ananth, Matthew Richardson and Mark Roomans (1997), Why Do Security Prices Change? A Transaction-Level Analysis of NYSE Stocks, Review of Financial Studies 10: 1035-1064.

Malloy, Christopher (2005), The Geography of Equity Analysis, Journal of Finance, 60:2, 719756.

Marsh, Ian W. and Ceire O'Rourke (2005), Customer Order Flow and Exchange Rate Movements: Is there Really Information Content?, Working Paper, Cass Business School, London.

Menkhoff, Lukas and Maik Schmeling (2008), Local Information in Foreign Exchange Markets, Journal of International Money and Finance, 27, 1383-1406.

Menkhoff, Lukas and Maik Schmeling (2010), Whose Trades Convey Information? Evidence from a Cross-Section of Traders, Journal of Financial Markets, 13, 101-128.

Osler, Carol (2008), Foreign Exchange Microstructure: A Survey of the Empirical Literature, Encyclopedia of Complexity and System Science (Springer: Berlin), forthcoming.

Osler, Carol, Lukas Menkhoff and Alexander Mende (2007), Price Discovery in Currency Markets, EFA 2006 Zurich Meetings Working Paper.

Osler, Carol, and Vitaliy Vandrovych (2009), Hedge Funds and the Origins of Private Information in Currency Markets, presented at the Third Annual Workshop on Market Microstructure, Cass Business School, City University London, May 1, 2009.

Parlour, Christine A. (1998), Price Dynamics in Limit Order Markets, Review of Financial Studies, 11:4, 786-816.

Parlour, Christine A. and Duane Seppi (2008), Limit Order Markets: A Survey, in: A.W.A. Boot and A.V. Thakor, Eds., Handbook of Financial Intermediation and Banking, forthcoming

Payne, Richard (2003), Informed Trade in Spot Foreign Exchange Markets: An Empirical Investigation, Journal of International Economics, 61, 307-329.

Peiers, Bettina (1997), Informed Traders, Intervention, and Price Leadership: A Deeper View of the Microstructure of the Foreign Exchange Market, Journal of Finance, 52:4, 15891614. 
Peterson, Mark and Eric Sirri (2002), Order Submission Strategies and the Curious Case of Marketable Limit Orders, Journal of Financial and Quantitative Analysis, 27:2, 221-241.

Rakowski, David and Xiaoxin Wang Beardsley (2008), Decomposing Liquidity along the Limit Order Book, Journal of Banking and Finance, 32, 1687-1698.

Ramadorai, Tarun (2008), What Determines Transaction Costs in Foreign Exchange Markets, International Journal of Finance and Economics, 13, 14-25.

Ranaldo, Angelo (2004), Order Aggressiveness in Limit Order Book Markets, Journal of Financial Markets, 7, 53-74.

Ranaldo, Angelo (2009), Segmentation and Time-of-day Patterns in Foreign Exchange Markets, Journal of Banking and Finance, 33, 2199-2206.

Rime, Dagfinn, Lucio Sarno and Elvira Sojli (2010) Exchange-rate Forecasting, Order Flow, and Macro Information, Journal of International Economics, 80, 72-88.

Rosu, Ioanid (2008), Liquidity and Information in Order Driven Markets, Working Paper, University of Chicago.

Rosu, Ioanid (2009), A Dynamic Model of the Limit Order Book, Review of Financial Studies, $22,4601-4641$.

Seppi, Duane J. (1997), Liquidity Provision with Limit Orders and a Strategic Specialist, Review of Financial Studies, 10:1, 103-150.

Tkatch, Isabel and Eugene Kandel (2008), Demand for the Immediacy of Execution: Time is Money, Working Paper, Georgia State University.

Wuyts, Gunther (2008), The Impact of Liquidity Shocks through the Order Book, Working Paper, University of Leuven. 


\section{Figure 1A. Intraday patterns in spreads and volatility}

The bars show average percentage spreads, the line shows average volatility, for the twelve successive time intervals that jointly comprise each daily trading session for the MICEX, Moscow Interbank Currency Exchange, which serves as the Russia-wide electronic order book for interdealer trading in rubles. Data cover the nine trading days from 11 through 21 March, 2002 , a period with 26,859 orders and 14,109 trades and include all orders placed and all trades. Volatility is measured as the standard deviation of midquote changes.

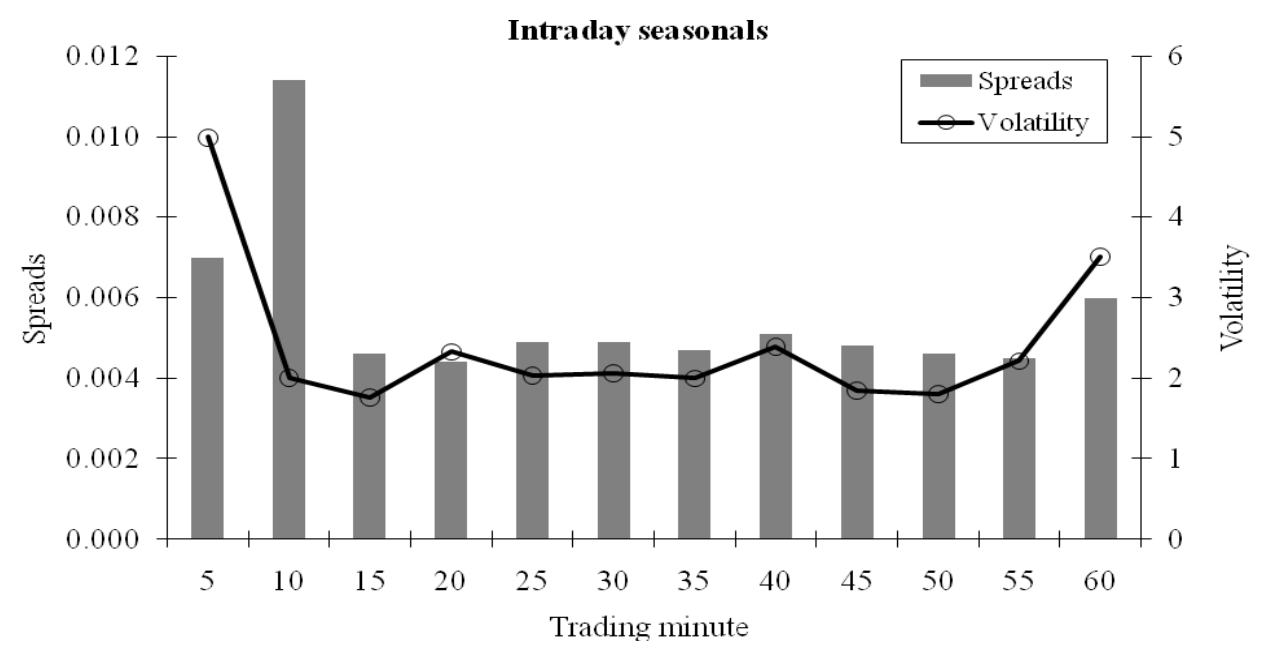

\section{Figure 1B. Intraday inflow of orders and order-book size}

In Panel A, the boxed line shows the number of orders outstanding (left axis) and the circled line shows the share of limit order placement (right axis) across the twelve successive time intervals of each trading session. Panel B shows the share of limit orders separately for informed (circles) and uninformed traders (boxes).
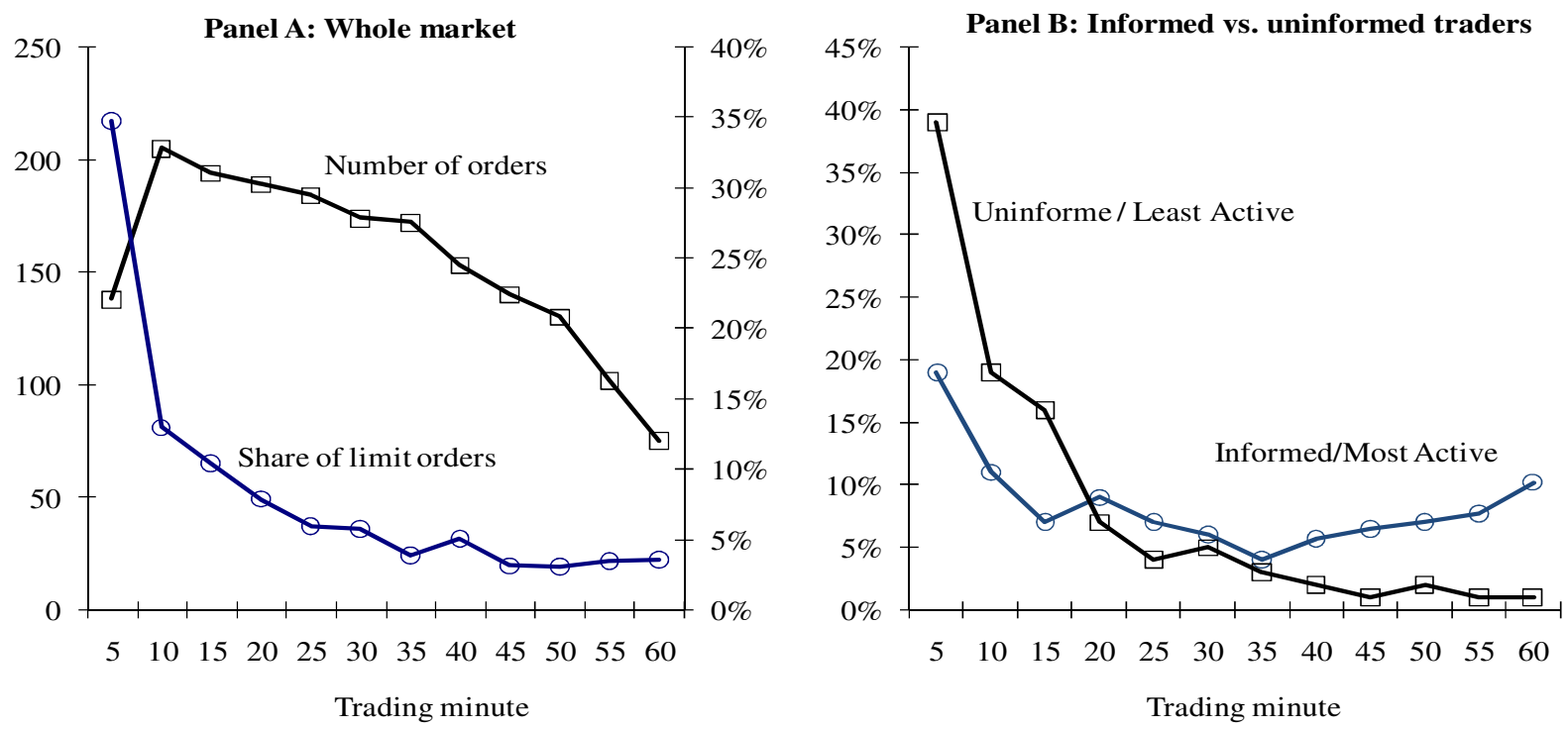


\section{Figure 2. Submission and taking rates}

Panel A shows submission rates for informed and uninformed traders for non-overlapping five minute intervals, averaged across all trading days in the sample. Panel B shows taking rates for the same samples. Note that the first minute of trading has been excluded, to reduce distortions associated with the market's lack of a pre-opening period during which the order book can be refilled.

\section{Panel A: Submission rates}

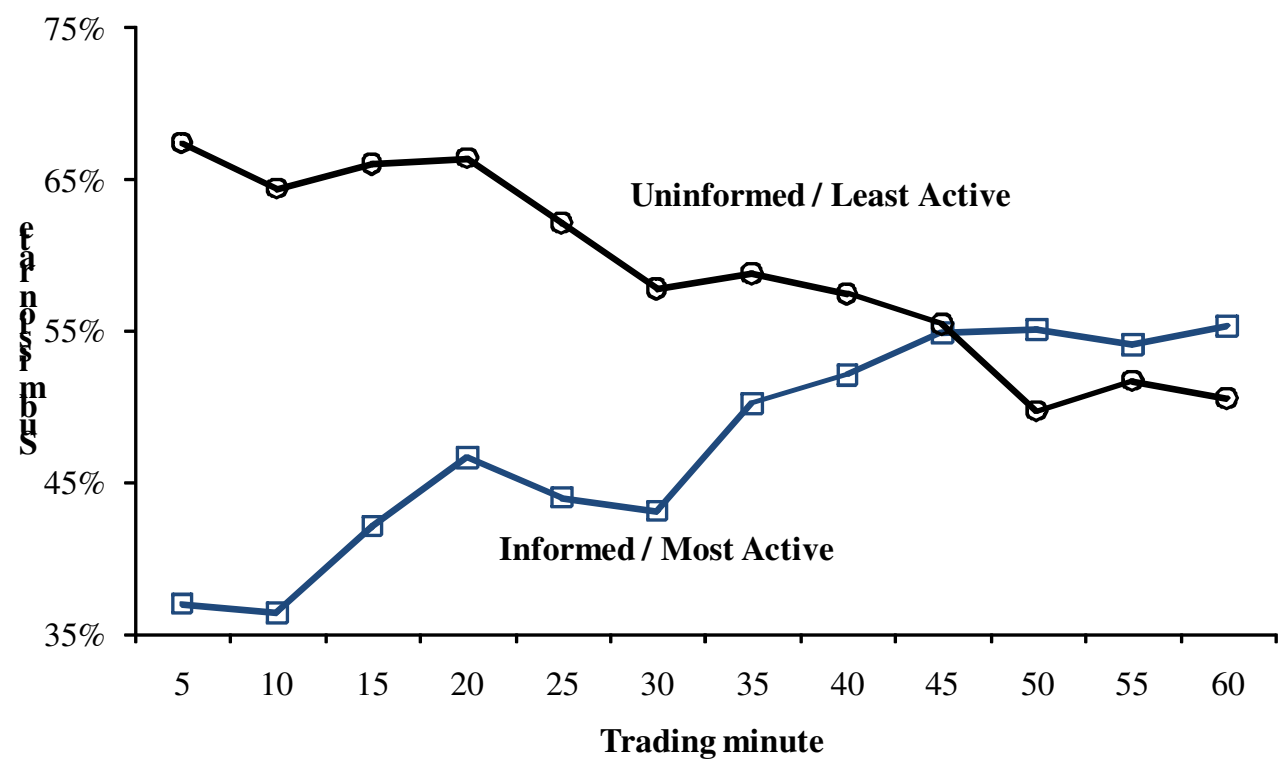

Panel B: Taking rates

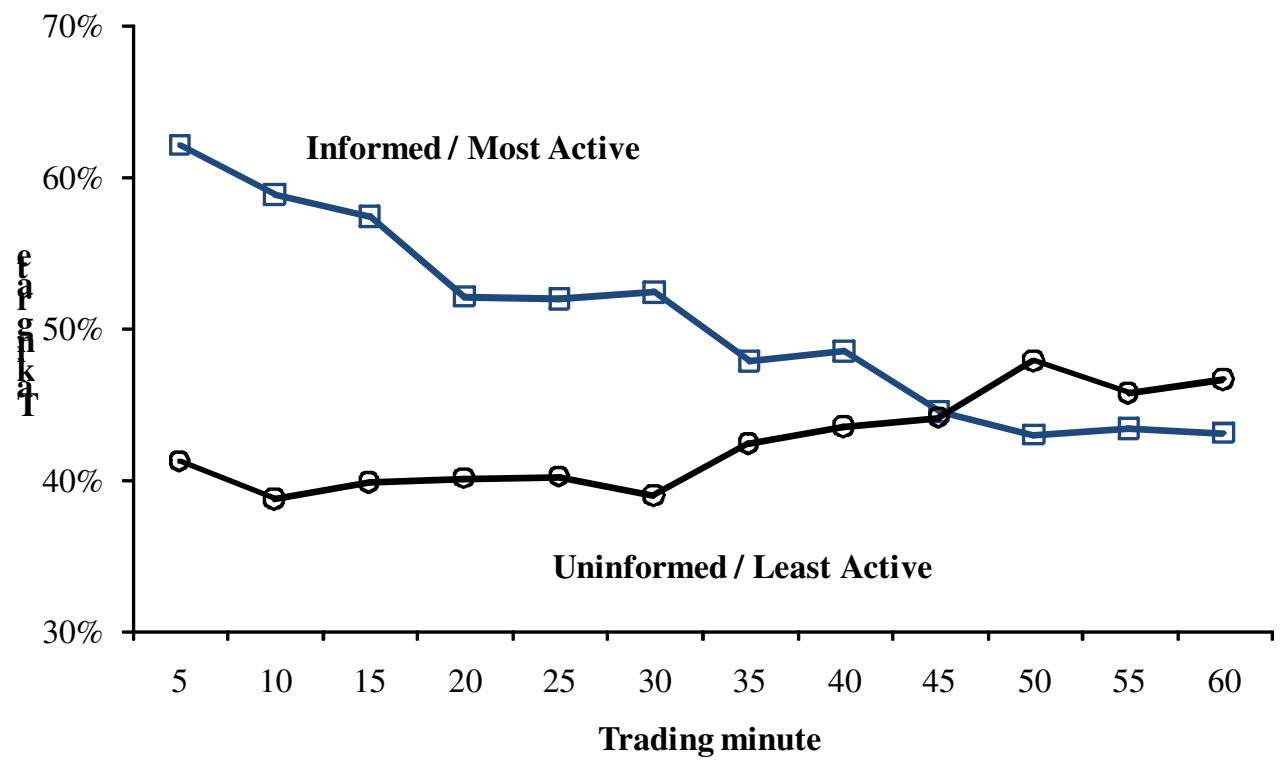




\section{Table 1. Descriptive statistics of order submissions}

This table shows descriptive statistics for the distribution of market orders, aggressive orders and patient orders on the Moscow Interbank Currency Exchange (MICEX), the Russia-wide electronic order book for interdealer trading in rubles. Data cover the nine trading days from 11 through 21 March, 2002, a period with 26,859 orders and 14,109 trades, and include all orders placed and all trades.

\begin{tabular}{lccccc}
\hline & $\begin{array}{c}\text { All } \\
\text { Traders }\end{array}$ & $\begin{array}{c}\text { Most Active } \\
\text { Quartile }\end{array}$ & $\begin{array}{c}\text { Least Active } \\
\text { Quartile }\end{array}$ & Center & Periphery \\
\hline $\begin{array}{l}\text { Number of traders } \\
\text { Traded Value Per Trader }\end{array}$ & 722 & 21 & 546 & 461 & 261 \\
$\quad$ (\$ Mill) & & & & \\
$\quad$ Market Orders & 1.0 & 5.5 & 0.3 & 1.2 & 0.5 \\
$\quad$ Aggressive Orders & 0.4 & 1.5 & 0.1 & 0.4 & 0.2 \\
$\quad$ Patient Orders & 1.9 & 11.1 & 0.6 & 2.4 & 1.0 \\
Order Number Per Trader & & & & & \\
$\quad$ Market Orders & 19.5 & 94.9 & 9.7 & 22.7 & 13.9 \\
Aggressive Orders & 4.7 & 12.2 & 3.6 & 4.5 & 5.1 \\
$\quad$ Patient Orders & 17.4 & 29.8 & 13.3 & 16.5 & 19.0 \\
Avg Order Size & & & & & \\
$\quad$ (\$ thous) & & & & & \\
Market Orders & 49.4 & 58.2 & 26.1 & 54.2 & 35.5 \\
$\quad$ Aggressive Orders & 75.4 & 125.0 & 36.8 & 97.5 & 40.8 \\
$\quad$ Patient Orders & 109.6 & 372.2 & 44.3 & 147.2 & 51.9 \\
\hline
\end{tabular}

\section{Table 2. Descriptive statistics for conditioning variables}

Data represent all orders and trades on the Moscow Interbank Currency Exchange (MICEX), the Russia-wide electronic order book for interdealer trading in rubles, over the nine trading days from 11 through 21 March, 2002.

\begin{tabular}{|c|c|c|c|c|c|c|c|}
\hline & \multirow[b]{2}{*}{ Mean } & \multicolumn{3}{|c|}{ Percentiles } & \multirow[b]{2}{*}{ Std. dev. } & \multirow[b]{2}{*}{ Skew } & \multirow[b]{2}{*}{ Kurt } \\
\hline & & 25 & 50 & 75 & & & \\
\hline Spread (per & 0.006 & 0.002 & 0.005 & 0.007 & 0.007 & 7.853 & 112.328 \\
\hline Volatility & 0.633 & 0.184 & 0.363 & 0.634 & 1.258 & 8.664 & 105.220 \\
\hline Depth, Same Side & 127,802 & 3,000 & 25,000 & 95,000 & 248,289 & 2.623 & 9.08 \\
\hline Depth, Opposite Side & 124,020 & 4,000 & 25,000 & 100,000 & 238,432 & 2.704 & 9.726 \\
\hline Momentum & 1.271 & -3.000 & 1.000 & 6.000 & 9.964 & 0.068 & 6.119 \\
\hline Trading Volun & 66.036 & 0.500 & 9.040 & 80.680 & 113.381 & 2.619 & 11.016 \\
\hline Trade Duration & 2.498 & 1.000 & 2.000 & 6.000 & 4.610 & 5.350 & 54.621 \\
\hline Time (trading minute) & 19.526 & 7.000 & 15.000 & 31.000 & 16.575 & 0.840 & 2.546 \\
\hline
\end{tabular}


Table 3. Order choice, informed and uninformed traders compared

Ordered logit estimates of the determinants of order choice. Dependent variable is an index that rises with order aggressiveness. Spreads and depth are measured immediately prior to order placement. Volatility, trading volume, and momentum are measured over the twenty seconds prior to order placement. Data represent all orders and trades on the Moscow Interbank Currency Exchange (MICEX), the Russia-wide electronic order book for interdealer trading in rubles, over the nine trading days from 11 through 21 March, 2002, a sample of 26,859 orders and 14,109 trades. (Figures in square brackets are $t$-statistics; $* 10$ percent significance; $* * 5$ percent significance; $* * * 1$ percent significance.)

\section{A. Information proxied by trading activity}

Traders are ranked by trading activity. Those with the most activity who are jointly responsible for one quarter of trading activity are taken to be informed; those with the least trading activity who are jointly responsible for one quarter of trading activity are taken to be uninformed.

\begin{tabular}{|c|c|c|c|c|c|c|c|c|}
\hline & \multicolumn{4}{|c|}{ Informed/Most Active Quartile } & \multicolumn{4}{|c|}{ Uninformed/Least Active Quartile } \\
\hline & \multirow{2}{*}{ Coefficient } & \multicolumn{3}{|c|}{ Marginal Effects } & \multirow{2}{*}{ Coefficient } & \multicolumn{3}{|c|}{ Marginal Effects } \\
\hline & & Patient & Aggress. & Market & & Patient & Aggress. & Market \\
\hline Spread & $\begin{array}{r}-0.010 \\
* * *[-3.08]\end{array}$ & 2.11 & 0.46 & -2.57 & $\begin{array}{r}-0.002 \\
* *[-2.19]\end{array}$ & 0.89 & -0.01 & -0.88 \\
\hline Volatility & $\begin{array}{r}-0.113 \\
* * *[-2.75]\end{array}$ & 1.96 & 0.40 & -2.36 & $\begin{array}{r}-0.047 \\
*[-1.87]\end{array}$ & 0.68 & -0.01 & -0.67 \\
\hline Depth, Same Side & $\begin{array}{r}0.453 \\
* * *[2.77]\end{array}$ & -1.47 & -0.31 & 1.78 & $\begin{array}{r}0.122 \\
{[1.01]}\end{array}$ & -0.31 & 0.00 & 0.31 \\
\hline Depth, Other Side & $\begin{array}{r}-0.746 \\
* * *[-3.74]\end{array}$ & 1.59 & 0.31 & -1.90 & $\begin{array}{r}-0.221 \\
*[-1.89]\end{array}$ & 0.38 & -0.03 & -0.35 \\
\hline Momentum & $\begin{array}{r}0.049 \\
* * *[11.98]\end{array}$ & -3.56 & -0.66 & 4.22 & $\begin{array}{r}0.013 \\
* * *[6.02]\end{array}$ & -0.11 & 0.01 & 0.12 \\
\hline Trading Volume & $\begin{array}{l}-0.170 \\
{[-0.32]}\end{array}$ & 0.12 & 0.04 & -0.16 & $\begin{array}{l}-0.045 \\
{[-0.43]}\end{array}$ & 0.08 & -0.00 & -0.07 \\
\hline Trade Duration & $\begin{array}{r}-0.042 \\
* * *[-5.99]\end{array}$ & 2.75 & -0.37 & -2.38 & $\begin{array}{r}-0.026 \\
* * *[-2.68]\end{array}$ & 1.98 & 0.21 & -2.19 \\
\hline Time & $\begin{array}{r}-0.005 \\
* *[-2.00]\end{array}$ & 2.09 & 0.50 & -2.59 & $\begin{array}{r}0.003 \\
* *[1.98]\end{array}$ & -1.30 & 0.01 & 1.31 \\
\hline $\operatorname{LR} \chi^{2}$ & $\begin{array}{r}375.43 \\
* * *(0.00)\end{array}$ & \multicolumn{3}{|c|}{ Unconditional Probabilities } & $\begin{array}{r}159.88 \\
* * *(0.00)\end{array}$ & \multicolumn{3}{|c|}{ Unconditional Probabilities } \\
\hline $\begin{array}{l}\text { Pseudo } \mathrm{R}^{2} \\
\text { Obs. }\end{array}$ & $\begin{array}{l}0.108 \\
2,725\end{array}$ & $24.56 \%$ & $10.30 \%$ & $65.14 \%$ & $\begin{array}{c}0.012 \\
12,817\end{array}$ & $45.07 \%$ & $11.16 \%$ & $43.77 \%$ \\
\hline
\end{tabular}


3B. Information proxied by location

Traders located in the financial centers of Moscow and St. Petersburg are assumed to be informed, others are assumed to be uninformed.

\begin{tabular}{|c|c|c|c|c|c|c|c|c|}
\hline & \multicolumn{4}{|c|}{ Informed/Financial Center } & \multicolumn{4}{|c|}{ Uninformed/Periphery } \\
\hline & \multirow{2}{*}{ Coefficient } & \multicolumn{3}{|c|}{ Marginal Effects } & \multirow{2}{*}{ Coefficient } & \multicolumn{3}{|c|}{ Marginal Effects } \\
\hline & & Patient & Aggress. & Market & & Patient & Aggress. & Market \\
\hline Spread & $\begin{array}{r}-0.004 \\
* *[-2.75]\end{array}$ & 0.89 & 0.04 & -0.93 & $\begin{array}{c}0.000 \\
{[0.12]}\end{array}$ & -0.05 & 0.00 & 0.05 \\
\hline Volatility & $\begin{array}{r}-0.082 \\
* *[-4.21]\end{array}$ & 1.37 & 0.09 & -1.46 & $\begin{array}{r}-0.040 \\
* *[-2.02]\end{array}$ & 0.78 & -0.05 & -0.83 \\
\hline Depth, Same Side & $\begin{array}{r}0.136 \\
* *[2.19]\end{array}$ & -0.42 & -0.02 & 0.44 & $\begin{array}{r}0.135 \\
*[1.77]\end{array}$ & -0.44 & 0.02 & 0.42 \\
\hline Depth, Other Side & $\begin{array}{r}-0.236 \\
* *[-2.40]\end{array}$ & 0.44 & 0.06 & -0.50 & $\begin{array}{r}0.001 \\
{[0.08]}\end{array}$ & -0.02 & 0.00 & 0.02 \\
\hline Momentum & $\begin{array}{r}0.052 \\
* *[30.98]\end{array}$ & -2.27 & -0.19 & 2.45 & $\begin{array}{r}0.020 \\
* *[7.64]\end{array}$ & -0.14 & 0.02 & 0.12 \\
\hline Trading Volume & $\begin{array}{l}-0.127 \\
{[-0.51]}\end{array}$ & 0.12 & 0.00 & -0.12 & $\begin{array}{r}0.019 \\
{[0.11]}\end{array}$ & -0.03 & 0.00 & 0.03 \\
\hline Trade Duration & $\begin{array}{r}-0.019 \\
* * *[-5.58]\end{array}$ & 1.76 & -0.21 & -1.55 & $\begin{array}{r}-0.020 \\
* * *[-2.44]\end{array}$ & 1.23 & 0.06 & -1.29 \\
\hline Time & $\begin{array}{r}-0.001 \\
* *[-2.01] \\
\end{array}$ & 0.32 & 0.02 & -0.34 & $\begin{array}{r}0.007 \\
* *[5.06] \\
\end{array}$ & -4.23 & 0.29 & 4.52 \\
\hline LR $\chi^{2}$ & $\begin{array}{r}1277.74 \\
* * *(0.00)\end{array}$ & \multicolumn{3}{|c|}{ Unconditional Probabilities } & $\begin{array}{r}186.23 \\
* * *(0.00)\end{array}$ & \multicolumn{3}{|c|}{ Unconditional Probabilities } \\
\hline $\begin{array}{l}\text { Pseudo } \mathrm{R}^{2} \\
\text { Obs. }\end{array}$ & $\begin{array}{r}0.041 \\
18,026 \\
\end{array}$ & 35.95 & $10.81 \%$ & $53.24 \%$ & $\begin{array}{l}0.013 \\
8,833 \\
\end{array}$ & $49.65 \%$ & $13.71 \%$ & $36.64 \%$ \\
\hline
\end{tabular}




\section{Table 4. Response of order choice to market shocks: entire market}

Table presents ordered logit estimates of the determinants of market-wide liquidity provision. Dependent variable is an index of order aggressiveness, with 1 corresponding to patient limit orders, 2 corresponding to aggressive limit orders, and 3 corresponding to market orders. Spread and depth variables are measured immediately prior to an order's placement. Volatility, trading volume, and

momentum are measured over the twenty seconds prior to an order's placement. Data represent all orders and trades on the Moscow Interbank Currency Exchange (MICEX), the Russia-wide electronic order book for interdealer trading in rubles. Data, which cover the nine trading days from 11 through 21 March, 2002, include 26,859 orders and 14,109 trades. (Figures in square brackets are $t$ statistics; * indicates significance at the 10 percent level; ** indicates significance at the 5 percent level; *** indicates significance at the 1 percent level.)

\begin{tabular}{|c|c|c|c|c|}
\hline & \multirow{2}{*}{ Coefficient } & \multicolumn{3}{|c|}{ Marginal Effects (semi-elasticity) } \\
\hline & & Patient & Aggressive & Market \\
\hline Spread & $\begin{array}{r}-0.001 \\
*[-1.78]\end{array}$ & $0.41 \%$ & $0.02 \%$ & $-0.43 \%$ \\
\hline Volatility & $\begin{array}{r}-0.095 \\
* * *[-4.74]\end{array}$ & $1.32 \%$ & $0.06 \%$ & $-1.38 \%$ \\
\hline Depth, Same Side & $\begin{array}{r}0.143 \\
* * *[2.78]\end{array}$ & $-0.43 \%$ & $-0.02 \%$ & $0.46 \%$ \\
\hline Depth, Other Side & $\begin{array}{r}-0.130 \\
* * *[-2.02]\end{array}$ & $0.35 \%$ & $0.01 \%$ & $-0.36 \%$ \\
\hline Momentum & $\begin{array}{r}0.039 \\
* * *[31.03]\end{array}$ & $-1.30 \%$ & $-0.06 \%$ & $1.36 \%$ \\
\hline Trading Volume & $\begin{array}{r}-0.083 \\
{[-0.45]}\end{array}$ & $0.11 \%$ & $0.00 \%$ & $-0.11 \%$ \\
\hline Trade Duration & $\begin{array}{r}-0.023 \\
* * *[-3.98]\end{array}$ & 1.92 & -0.09 & -1.83 \\
\hline Time & $\begin{array}{r}0.003 \\
* * *[3.40] \\
\end{array}$ & $-1.26 \%$ & $-0.05 \%$ & $1.31 \%$ \\
\hline $\operatorname{LR} \chi^{2}$ & $\begin{array}{r}1389.41 \\
* * *(0.00)\end{array}$ & \multicolumn{3}{|c|}{ Unconditional Probabilities } \\
\hline $\begin{array}{l}\text { Pseudo } \mathrm{R}^{2} \\
\text { Obs. }\end{array}$ & $\begin{array}{c}0.032 \\
26,859\end{array}$ & $47.61 \%$ & $11.79 \%$ & $40.60 \%$ \\
\hline
\end{tabular}




\section{Table 5. Robustness to alternative variable definitions}

This table shows ordered logit estimation results as in Table 3A, where information is proxied by trading activity, with certain explanatory variables redefined. In I, the "high-low range" over the 20 seconds prior to an order replaces standard deviation of returns as a volatility measure. In II, variables are defined as in Table 3A except "price momentum," the cumulative change in midquote returns over the preceding 20 seconds, replaces order-flow momentum. In III the "time" rows represent time dummies that are equal to one when an order falls in the respective interval. Table provides coefficients, with standard errors in square brackets. * indicates significance at the 10 percent level; ** indicates significance at the 5 percent level; *** indicates significance at the 1 percent level.)

\begin{tabular}{|c|c|c|c|c|c|c|}
\hline & \multicolumn{3}{|c|}{ Informed/Most Active Quartile } & \multicolumn{3}{|c|}{ Uninformed/Least Active Quartile } \\
\hline & (I) & (II) & (III) & (I) & (II) & (III) \\
\hline Spread & $\begin{array}{r}-0.011 \\
* * *[-3.82]\end{array}$ & $\begin{array}{r}-0.006 \\
* *[-2.32]\end{array}$ & $\begin{array}{r}-0.012 \\
* * *[-2.74]\end{array}$ & $\begin{array}{r}-0.002 \\
*[-1.89]\end{array}$ & $\begin{array}{r}-0.002 \\
*[-1.91]\end{array}$ & $\begin{array}{r}-0.002 \\
* *[-2.10]\end{array}$ \\
\hline Volatility & & $\begin{array}{r}-0.134 \\
* * *[-2.55]\end{array}$ & $\begin{array}{r}-0.121 \\
* * *[-2.28]\end{array}$ & & $\begin{array}{r}-0.041 \\
*[-1.84]\end{array}$ & $\begin{array}{r}-0.032 \\
*[-1.68]\end{array}$ \\
\hline $\begin{array}{l}\text { High-Low } \\
\text { range }\end{array}$ & $\begin{array}{r}-0.139 \\
* * *[-2.22]\end{array}$ & & & $\begin{array}{r}-0.035 \\
*[-1.76]\end{array}$ & & \\
\hline $\begin{array}{l}\text { Depth, Same } \\
\text { Side }\end{array}$ & $\begin{array}{r}0.432 \\
* * *[2781\end{array}$ & $\begin{array}{r}0.446 \\
* * *[265]\end{array}$ & $\begin{array}{r}0.491 \\
* * *[2.51]\end{array}$ & $\begin{array}{r}0.117 \\
{[1.34]}\end{array}$ & $\begin{array}{r}0.129 \\
{[1.11]}\end{array}$ & $\begin{array}{r}0.110 \\
{[1.38]}\end{array}$ \\
\hline Depth, Other & -0.699 & -0.671 & -0.608 & -0.195 & -0.242 & -0.220 \\
\hline Side & $* * *[-3.59]$ & $* * *[-3.68]$ & $* * *[-3.73]$ & {$[-1.32]$} & $*[-1.73]$ & {$[-1.30]$} \\
\hline Momentum & $\begin{array}{r}0.060 \\
* * *[10.06]\end{array}$ & & $\begin{array}{r}0.058 \\
* * *[9.57]\end{array}$ & $\begin{array}{r}0.012 \\
* * *[5.44]\end{array}$ & & $\begin{array}{r}0.013 \\
* * *[6.21]\end{array}$ \\
\hline $\begin{array}{l}\text { Price } \\
\text { Momentum }\end{array}$ & & $\begin{array}{r}0.203 \\
* * *[5.12]\end{array}$ & & & $\begin{array}{r}0.151 \\
* *[2.09]\end{array}$ & \\
\hline $\begin{array}{l}\text { Trading } \\
\text { Volume }\end{array}$ & $\begin{array}{c}-0.238 \\
{[-0.52]}\end{array}$ & $\begin{array}{c}-0.223 \\
{[-0.69]}\end{array}$ & $\begin{array}{l}-0.309 \\
{[-0.41]}\end{array}$ & $\begin{array}{l}-0.061 \\
{[-0.28]}\end{array}$ & $\begin{array}{l}-0.080 \\
{[-0.31]}\end{array}$ & $\begin{array}{l}-0.023 \\
{[-0.17]}\end{array}$ \\
\hline Trade Duration & $\begin{array}{r}-0.021 \\
* * *[-6.21]\end{array}$ & $\begin{array}{r}-0.031 \\
* * *[-5.38]\end{array}$ & $\begin{array}{r}-0.040 \\
* * *[-6.33]\end{array}$ & $\begin{array}{r}-0.011 \\
* *[-2.55]\end{array}$ & $\begin{array}{r}-0.019 \\
* *[-2.11]\end{array}$ & $\begin{array}{r}-0.018 \\
* *[-2.00]\end{array}$ \\
\hline Time & $\begin{array}{r}-0.005 \\
* *-2.01]\end{array}$ & $\begin{array}{r}-0.005 \\
* *[-2.34]\end{array}$ & & $\begin{array}{r}0.003 \\
* *[2.15]\end{array}$ & $\begin{array}{r}0.002 \\
* *[1.99]\end{array}$ & \\
\hline Time $1-10$ & & & $\begin{array}{r}0.015 \\
*[1.92]\end{array}$ & & & $\begin{array}{r}-0.192 \\
* *[-2.21]\end{array}$ \\
\hline Time 11-20 & & & $\begin{array}{r}0.021 \\
*[1.87]\end{array}$ & & & $\begin{array}{r}-0.220 \\
* *[-2.10]\end{array}$ \\
\hline Time 21-30 & & & $\begin{array}{r}0.012 \\
* *[2.10]\end{array}$ & & & $\begin{array}{r}-0.149 \\
*[-1.92]\end{array}$ \\
\hline Time $31-40$ & & & $\begin{array}{l}-0.006 \\
{[-0.59]}\end{array}$ & & & $\begin{array}{r}-0.089 \\
*[-1.71]\end{array}$ \\
\hline Time $41-50$ & & & $\begin{array}{r}-0.019 \\
* *[-2.06] \\
\end{array}$ & & & $\begin{array}{r}0.157 \\
* *[1.94] \\
\end{array}$ \\
\hline $\operatorname{LR} \chi 2$ & $\begin{array}{r}372.46 \\
* * *(0.00)\end{array}$ & $\begin{array}{r}345.12 \\
* * *(0.00)\end{array}$ & $\begin{array}{r}379.08 \\
* * *(0.00)\end{array}$ & $\begin{array}{r}165.78 \\
* * *(0.00)\end{array}$ & $\begin{array}{r}122.03 \\
* * *(0.00)\end{array}$ & $\begin{array}{r}170.60 \\
* * *(0.00)\end{array}$ \\
\hline Pseudo R2 & 0.107 & 0.101 & 0.110 & 0.012 & 0.010 & 0.017 \\
\hline Obs. & 2,725 & 2,725 & 2,725 & 12,817 & 12,817 & 12,817 \\
\hline
\end{tabular}


Table 6. Lagged aggressiveness

This table shows coefficient estimates from ordered logit estimates for all traders, financial center traders, periphery traders, the quartile of most active traders and the quartile of least active traders. All explanatory variables and notations are identical to those used in Tables 3 and 4, except for an additional explanatory variable "Last Order". This dummy variable equals one when the last order just was a market order with the same direction as the current order.

\begin{tabular}{|c|c|c|c|c|c|}
\hline & All traders & $\begin{array}{l}\text { Informed/ } \\
\text { Most active }\end{array}$ & $\begin{array}{l}\text { Uninformed/ } \\
\text { Least active }\end{array}$ & $\begin{array}{l}\text { Informed/ } \\
\text { Center }\end{array}$ & $\begin{array}{l}\text { Uninformed/ } \\
\text { Periphery }\end{array}$ \\
\hline \multirow{2}{*}{ Last Order } & 1.041 & 1.001 & 0.742 & 1.032 & 0.838 \\
\hline & $* * *[27.80]$ & $* * *[11.91]$ & $* * *[15.14]$ & $* * *[21.03]$ & $* * *[20.67]$ \\
\hline \multirow{2}{*}{ Spread } & -0.002 & -0.003 & -0.002 & -0.003 & -0.001 \\
\hline & $* * *[-3.12]$ & $*[-1.95]$ & $*[-1.78]$ & $* * *[-2.80]$ & {$[-0.56]$} \\
\hline \multirow{2}{*}{ Volatility } & -0.043 & -0.103 & -0.046 & -0.063 & -0.025 \\
\hline & $* * *[-2.75]$ & $* *[-1.98]$ & {$[-1.62]$} & $* * *[-3.13]$ & {$[-1.11]$} \\
\hline \multirow{2}{*}{ Depth, Same Side } & 0.067 & 0.330 & -0.092 & 0.042 & 0.113 \\
\hline & {$[1.40]$} & $* *[2.12]$ & {$[-1.44]$} & {$[0.51]$} & [1.19] \\
\hline \multirow{2}{*}{ Depth, Other Side } & -0.053 & -0.420 & 0.087 & -0.125 & 0.100 \\
\hline & {$[-1.14]$} & $* *[-2.32]$ & $*[1.69]$ & $* *[-2.08]$ & [1.16] \\
\hline \multirow{2}{*}{ Momentum } & 0.019 & 0.032 & 0.011 & 0.023 & 0.009 \\
\hline & $* * *[11.32]$ & $* * *[7.65]$ & $* * *[5.47]$ & $* * *[13.92]$ & $* * *[4.29]$ \\
\hline \multirow{2}{*}{ Trading Volume } & -0.034 & -0.095 & -0.102 & -0.020 & -0.052 \\
\hline & {$[-0.33]$} & {$[-0.67]$} & {$[-1.32]$} & {$[-0.05]$} & {$[-0.23]$} \\
\hline \multirow{2}{*}{ Trade Duration } & -0.017 & -0.030 & -0.012 & -0.021 & -0.016 \\
\hline & $* * *[-3.98]$ & $* * *[-4.29]$ & $* *[-2.20]$ & $* * *[-4.78]$ & $* *[-2.12]$ \\
\hline \multirow{2}{*}{ Time } & 0.003 & -0.003 & 0.004 & -0.002 & 0.007 \\
\hline & $* * *[3.99]$ & $* *[-2.03]$ & $* * *[3.76]$ & $* *[-1.98]$ & $* * *[5.39]$ \\
\hline \multirow{2}{*}{$\operatorname{LR} \chi^{2}$} & 3004.21 & 1321.17 & 1677.82 & 5334.01 & 1498.44 \\
\hline & $* * *(0.00)$ & $* * *(0.00)$ & $* * *(0.00)$ & $* * *(0.00)$ & $* * *(0.00)$ \\
\hline Pseudo $\mathrm{R}^{2}$ & 0.141 & 0.222 & 0.076 & 0.154 & 0.083 \\
\hline Obs. & 26,859 & 2,725 & 12,817 & 18,026 & 8,833 \\
\hline
\end{tabular}


Table 7. Further controls

This table shows coefficient estimates from ordered logit estimates for all traders, financial center traders, periphery traders, the quartile of most active traders and the quartile of least active traders. All explanatory variables and notations are identical to those used in Tables 3 and 4, except for additional control variables "spread $\times$ depth, other side" (interaction term of spread and depth, other side), "volatility $\times$ lagged depth" (interaction term of volatility and lagged average depth) and "arrival rate" (monetary value of submitted orders over the last 20 seconds). Furthermore, we drop the trade duration variable and replace it by "Duration, Same Side" (duration in seconds between the last two orders on the same side of the order book as the current order submission) and "Duration, Other Side" (duration in seconds between the last two orders on the other side of the order book as the current order submission).

(continued on next page) 
Table 7. (continued)

\begin{tabular}{|c|c|c|c|c|c|}
\hline & All traders & $\begin{array}{l}\text { Informed/ } \\
\text { Most active }\end{array}$ & $\begin{array}{l}\text { Uninformed/ } \\
\text { Least active }\end{array}$ & $\begin{array}{c}\text { Informed/ } \\
\text { Center }\end{array}$ & $\begin{array}{l}\text { Uninformed/ } \\
\text { Periphery }\end{array}$ \\
\hline \multirow{2}{*}{ Spread } & -0.002 & -0.008 & -0.003 & -0.006 & -0.001 \\
\hline & $* * *[-2.91]$ & $* * *[-3.23]$ & $* *[-2.31]$ & $* * *[-4.29]$ & {$[-1.33]$} \\
\hline \multirow{2}{*}{ Volatility } & -0.028 & -0.119 & -0.038 & -0.066 & -0.034 \\
\hline & $* * *[-3.70]$ & $* *[-2.21]$ & {$[-1.85]$} & $* * *[-3.80]$ & $*[-1.89]$ \\
\hline \multirow{2}{*}{ Depth, Same Side } & 0.107 & 0.441 & 0.134 & 0.091 & 0.127 \\
\hline & $*[1.91]$ & $* * *[3.01]$ & [1.44] & [1.59] & $*[1.91]$ \\
\hline \multirow{2}{*}{ Depth, Other Side } & -0.211 & -0.864 & -0.220 & -0.277 & 0.000 \\
\hline & $* *[-2.11]$ & $* * *[-2.77]$ & $*[-1.69]$ & $* *[2.49]$ & {$[0.07]$} \\
\hline \multirow{2}{*}{ Momentum } & 0.041 & 0.064 & 0.024 & 0.055 & 0.024 \\
\hline & $* * *[30.02]$ & $* * *[13.28]$ & $* * *[7.51]$ & $* * *[31.17]$ & $* * *[8.08]$ \\
\hline \multirow{2}{*}{ Trading Volume } & -0.034 & -0.102 & -0.012 & -0.096 & 0.010 \\
\hline & {$[0.45]$} & {$[-0.21]$} & {$[-0.02]$} & {$[-0.58]$} & {$[0.05]$} \\
\hline \multirow{2}{*}{ Time } & 0.003 & -0.004 & 0.002 & -0.001 & 0.008 \\
\hline & $* * *[3.11]$ & $* *[-2.13]$ & $* *[2.02]$ & $*[-1.84]$ & $* * *[4.99]$ \\
\hline \multirow{2}{*}{$\begin{array}{l}\text { Spread } \times \\
\text { Depth, Other Side }\end{array}$} & 0.066 & 0.058 & 0.088 & 0.100 & 0.047 \\
\hline & {$[0.72]$} & {$[0.30]$} & {$[1.42]$} & {$[0.87]$} & {$[0.20]$} \\
\hline \multirow{2}{*}{$\begin{array}{l}\text { Volatility } \times \\
\text { Lagged Depth }\end{array}$} & -0.118 & -0.048 & -0.230 & -0.068 & -0.185 \\
\hline & $* *[-2.00]$ & {$[-1.54]$} & $* * *[-2.07]$ & {$[-1.44]$} & $* *[-2.40]$ \\
\hline \multirow{2}{*}{ Arrival rate } & -0.045 & -0.087 & -0.010 & -0.068 & -0.018 \\
\hline & {$[-0.71]$} & $*[-1.72]$ & {$[-0.17]$} & {$[-1.32]$} & {$[-0.22]$} \\
\hline \multirow{2}{*}{$\begin{array}{l}\text { Trade Duration, Same } \\
\text { Side }\end{array}$} & -0.32 & -0.049 & -0.028 & -0.025 & -0.031 \\
\hline & $* * *[-4.23]$ & $* * *[-5.03]$ & $* *[-2.10]$ & $* * *[-4.19]$ & $* * *[-2.68]$ \\
\hline \multirow{2}{*}{$\begin{array}{l}\text { Trade Duration, Other } \\
\text { Side }\end{array}$} & -0.13 & -0.011 & -0.016 & 0.009 & -0.028 \\
\hline & {$[-1.09]$} & {$[-1.45]$} & {$[-0.93]$} & [0.43] & $*[-1.98]$ \\
\hline \multirow{2}{*}{$\operatorname{LR} \chi^{2}$} & 1432.10 & 487.92 & 170.24 & 1303.19 & 191.17 \\
\hline & $* * *(0.00)$ & $* * *(0.00)$ & $* * *(0.00)$ & $* * *(0.00)$ & $* * *(0.00)$ \\
\hline \multirow{2}{*}{$\begin{array}{l}\text { Pseudo } R^{2} \\
\text { Obs. }\end{array}$} & 0.035 & 0.116 & 0.018 & 0.042 & 0.015 \\
\hline & 26,859 & 2,725 & 12,817 & 18,026 & 8,833 \\
\hline
\end{tabular}




\section{CESifo Working Paper Series}

for full list see www.cesifo-group.org/wp

(address: Poschingerstr. 5, 81679 Munich, Germany, office@cesifo.de)

2989 Helmut Rainer and Thomas Siedler, Family Location and Caregiving Patterns from an International Perspective, March 2010

2990 Toru Kikuchi and Ngo Van Long, A Simple Model of Service Offshoring with Time Zone Differences, March 2010

2991 Assaf Razin, Efraim Sadka and Benjarong Suwankiri, Migration and the Welfare State: Dynamic Political-Economy Theory, March 2010

2992 Bård Harstad, Buy Coal! Deposit Markets Prevent Carbon Leakage, March 2010

2993 Axel Dreher, Stephan Klasen, James Raymond Vreeland and Eric Werker, The Costs of Favoritism: Is Politically-driven Aid less Effective?, March 2010

2994 Sven Neelsen and Thomas Stratmann, Effects of Prenatal and Early Life Malnutrition: Evidence from the Greek Famine, March 2010

2995 Claude Hillinger and Bernd Süssmuth, The Quantity Theory of Money: An Assessment of its Real Linchpin Prediction, March 2010

2996 Matthew M. Chingos and Martin R. West, Do More Effective Teachers Earn More Outside of the Classroom?, March 2010

2997 Laurence Jacquet and Dirk Van de gaer, A Comparison of Optimal Tax Policies when Compensation or Responsibility Matter, March 2010

2998 Valentina Bosetti, Carlo Carraro, Romain Duval and Massimo Tavoni, What Should we Expect from Innovation? A Model-Based Assessment of the Environmental and Mitigation Cost Implications of Climate-Related R\&D, March 2010

2999 Scott Alan Carson, Nineteenth Century Stature and Family Size: Binding Constraint or Productive Labor Force?, March 2010

3000 Jukka Pirttilä and Ilpo Suoniemi, Public Provision, Commodity Demand and Hours of Work: An Empirical Analysis, March 2010

3001 Bertrand Candelon and Franz C. Palm, Banking and Debt Crises in Europe: The Dangerous Liaisons?, March 2010

3002 Joan Costa-i-Font and Marin Gemmill-Toyama, Does Cost Sharing really Reduce Inappropriate Prescriptions?, March 2010

3003 Scott Barrett, Climate Treaties and Backstop Technologies, March 2010 
3004 Hans Jarle Kind, Tore Nilssen and Lars Sørgard, Price Coordination in Two-Sided Markets: Competition in the TV Industry, March 2010

3005 Jay Pil Choi and Heiko Gerlach, Global Cartels, Leniency Programs and International Antitrust Cooperation, March 2010

3006 Aneta Hryckiewicz and Oskar Kowalewski, Why do Foreign Banks Withdraw from other Countries? A Panel Data Analysis, March 2010

3007 Eric A. Hanushek and Ludger Woessmann, Sample Selectivity and the Validity of International Student Achievement Tests in Economic Research, March 2010

3008 Dennis Novy, International Trade and Monopolistic Competition without CES: Estimating Translog Gravity, April 2010

3009 Yin-Wong Cheung, Guonan Ma and Robert N. McCauley, Renminbising China's Foreign Assets, April 2010

3010 Michel Beine and Sara Salomone, Migration and Networks: Does Education Matter more than Gender?, April 2010

3011 Friedrich Schneider, Tilman Brück and Daniel Meierrieks, The Economics of Terrorism and Counter-Terrorism: A Survey (Part I), April 2010

3012 Friedrich Schneider, Tilman Brück and Daniel Meierrieks, The Economics of Terrorism and Counter-Terrorism: A Survey (Part II), April 2010

3013 Frederick van der Ploeg and Steven Poelhekke, The Pungent Smell of "Red Herrings": Subsoil Assets, Rents, Volatility and the Resource Curse, April 2010

3014 Vjollca Sadiraj, Jan Tuinstra and Frans van Winden, Identification of Voters with Interest Groups Improves the Electoral Chances of the Challenger, April 2010

3015 Guglielmo Maria Caporale, Davide Ciferri and Alessandro Girardi, Time-Varying Spot and Futures Oil Price Dynamics, April 2010

3016 Scott Alan Carson, Racial Differences in Body-Mass Indices for Men Imprisoned in $19^{\text {th }}$ Century US Prisons: A Multinomial Approach, April 2010

3017 Alessandro Fedele, Paolo M. Panteghini and Sergio Vergalli, Optimal Investment and Financial Strategies under Tax Rate Uncertainty, April 2010

3018 Laurence Jacquet, Take it or Leave it: Take-up, Optimal Transfer Programs, and Monitoring, April 2010

3019 Wilhelm Kohler and Jens Wrona, Offshoring Tasks, yet Creating Jobs?, April 2010

3020 Paul De Grauwe, Top-Down versus Bottom-Up Macroeconomics, April 2010

3021 Karl Ove Aarbu, Demand Patterns for Treatment Insurance in Norway, April 2010 
3022 Toke S. Aidt and Jayasri Dutta, Fiscal Federalism and Electoral Accountability, April 2010

3023 Bahram Pesaran and M. Hashem Pesaran, Conditional Volatility and Correlations of Weekly Returns and the VaR Analysis of 2008 Stock Market Crash, April 2010

3024 Stefan Buehler and Dennis L. Gärtner, Making Sense of Non-Binding Retail-Price Recommendations, April 2010

3025 Leonid V. Azarnert, Immigration, Fertility, and Human Capital: A Model of Economic Decline of the West, April 2010

3026 Christian Bayer and Klaus Wälde, Matching and Saving in Continuous Time: Theory and 3026-A Matching and Saving in Continuous Time: Proofs, April 2010

3027 Coen N. Teulings and Nick Zubanov, Is Economic Recovery a Myth? Robust Estimation of Impulse Responses, April 2010

3028 Clara Graziano and Annalisa Luporini, Optimal Delegation when the Large Shareholder has Multiple Tasks, April 2010

3029 Erik Snowberg and Justin Wolfers, Explaining the Favorite-Longshot Bias: Is it RiskLove or Misperceptions?, April 2010

3030 Doina Radulescu, The Effects of a Bonus Tax on Manager Compensation and Welfare, April 2010

3031 Helmut Lütkepohl, Forecasting Nonlinear Aggregates and Aggregates with Timevarying Weights, April 2010

3032 Silvia Rocha-Akis and Ronnie Schöb, Welfare Policy in the Presence of Unionised Labour and Internationally Mobile Firms, April 2010

3033 Steven Brakman, Robert Inklaar and Charles van Marrewijk, Structural Change in OECD Comparative Advantage, April 2010

3034 Dirk Schindler and Guttorm Schjelderup, Multinationals, Minority Ownership and TaxEfficient Financing Structures, April 2010

3035 Christian Lessmann and Gunther Markwardt, Decentralization and Foreign Aid Effectiveness: Do Aid Modality and Federal Design Matter in Poverty Alleviation?, April 2010

3036 Eva Deuchert and Conny Wunsch, Evaluating Nationwide Health Interventions when Standard Before-After Doesn't Work: Malawi's ITN Distribution Program, April 2010

3037 Eric A. Hanushek and Ludger Woessmann, The Economics of International Differences in Educational Achievement, April 2010 
3038 Frederick van der Ploeg, Aggressive Oil Extraction and Precautionary Saving: Coping with Volatility, April 2010

3039 Ainura Uzagalieva, Evžen Kočenda and Antonio Menezes, Technological Imitation and Innovation in New European Union Markets, April 2010

3040 Nicolas Sauter, Jan Walliser and Joachim Winter, Tax Incentives, Bequest Motives, and the Demand for Life Insurance: Evidence from two Natural Experiments in Germany, April 2010

3041 Matthias Wrede, Multinational Capital Structure and Tax Competition, April 2010

3042 Burkhard Heer and Alfred Maussner, A Note on the Computation of the Equity Premium and the Market Value of Firm Equity, April 2010

3043 Kristiina Huttunen, Jukka Pirttilä and Roope Uusitalo, The Employment Effects of Low-Wage Subsidies, May 2010

3044 Matthias Kalkuhl and Ottmar Edenhofer, Prices vs. Quantities and the Intertemporal Dynamics of the Climate Rent, May 2010

3045 Bruno S. Frey and Lasse Steiner, Pay as you Go: A New Proposal for Museum Pricing, May 2010

3046 Henning Bohn and Charles Stuart, Population under a Cap on Greenhouse Gas Emissions, May 2010

3047 Balázs Égert and Rafal Kierzenkowski, Exports and Property Prices in France: Are they Connected?, May 2010

3048 Thomas Eichner and Thorsten Upmann, Tax-Competition with Involuntary Unemployment, May 2010

3049 Taiji Furusawa, Kazumi Hori and Ian Wooton, A Race beyond the Bottom: The Nature of Bidding for a Firm, May 2010

3050 Xavier Vives, Competition and Stability in Banking, May 2010

3051 Thomas Aronsson and Erkki Koskela, Redistributive Income Taxation under Outsourcing and Foreign Direct Investment, May 2010

3052 Michael Melvin and Duncan Shand, Active Currency Investing and Performance Benchmarks, May 2010

3053 Sören Blomquist and Laurent Simula, Marginal Deadweight Loss when the Income Tax is Nonlinear, May 2010

3054 Lukas Menkhoff, Carol L. Osler and Maik Schmeling, Limit-Order Submission Strategies under Asymmetric Information, May 2010 